\title{
Mechanisms and anticarcinogenic effects of diet-related apoptosis in the intestinal mucosa
}

\author{
Ian T. Johnson \\ Institute of Food Research, Norwich Research Park, Colney, Norwich NR4 7UA, UK
}

\begin{abstract}
There is now ample epidemiological evidence to show that the wide international variations in the incidence of both adenomatous polyps and colorectal cancer are linked to diet, but the mechanisms through which particular dietary constituents influence the onset of neoplasia are poorly understood. The crypt epithelial cells of the human gastrointestinal mucosa are amongst the most rapidly proliferating tissues in the body, and those of the colorectum are particularly vulnerable to neoplasia. Within the crypt, continuous division of basally localized stem cells gives rise to daughter cells that may divide once or twice again, before differentiating and migrating to the mucosal surface. The majority of nascent crypt epithelial cells differentiate, become senescent and are shed into the gut lumen, but a small proportion die by apoptosis soon after cell division. Various lines of evidence suggest that these pathways of programmed cell death provide a protective mechanism against induction of neoplasia by removing genetically damaged stem cells before they can divide further and give rise to precancerous lesions. There is evidence that the shortchain fatty acid butyrate and several different classes of food constituents, including some polyunsaturated fatty acids, flavonoids and glucosinolate breakdown products, can regulate the processes of cell proliferation and death in vitro, and in colorectal crypts in vivo. All three classes of food components suppress the emergence of aberrant crypt foci in animal models of carcinogenesis. The cellular mechanisms underlying these phenomena, and their possible significance for human health, are discussed.
\end{abstract}

Diet: Cancer: Intestine: Apoptosis: Crypt cells

\footnotetext{
Abbreviations: ACF, aberrant crypt foci; DHA, docosahexaenoic acid; DMH, 1,2-dimethylhydrazine; EPA, eicosapentaenoic acid; FAP, familial adenomatous polyposis; ICE, interleukin- $1 \beta$-converting enzyme; NSAID, non-steroidal anti-inflammatory drugs; PUFA, polyunsaturated fatty acids; SCFA, short-chain fatty acids; TUNEL, terminal deoxynucleotidyl transferase-mediated deoxyuridine triphosphate biotin nick-end labelling.
}

Corresponding author: Professor Ian T. Johnson, fax +44 1603 255267, email ian.johnson@bbsrc.ac.uk 


\section{Introduction}

The mucosal surfaces of the gut are exposed throughout life to an immensely complex variety of nutrients, xenobiotics, toxins and infectious agents. In both the small and large intestines, a single layer of columnar epithelium transfers nutrients and fluid to the circulation, whilst maintaining an essential barrier against toxins and infection. The mature epithelial cells undergo a form of programmed cell death and are shed continuously into the gut lumen, but the integrity of the mucosal surface is maintained by new cells that emerge from an array of blind-ending glandular crypts and migrate to the villi, or to the gently ridged inter-cryptal zones of the colon and rectum. Every crypt is a self-contained proliferating unit. Although crypt cell mitosis is balanced primarily by exfoliation of surface cells, there is also a smaller component of cell loss resulting from programmed cell death in the deeper, proliferative regions of the crypt.

Much of the gastrointestinal mucosa is prone to cancers that develop in the mucosal epithelium. In the UK, carcinomas of the digestive system account for about $25 \%$ of all deaths from cancer (Lennard-Jones, 2001). There are, however, major geographical variations in this figure, even within Europe, and it is generally accepted that much of this variation is due to environmental factors. Dietary components are thought to influence the development of cancers in the human digestive tract through a variety of mechanisms. A number of food-borne colorectal carcinogens have now been identified, including polycyclic aromatic hydrocarbons, heterocyclic aromatic amines (Adamson et al. 1996) and N-nitroso compounds (Bingham et al. 1996), but it is unlikely that geographical variations in the prevalence of the disease can be accounted for entirely by differences in the exposure of populations to these substances (Lutz \& Schlatter, 1992). Indirect evidence suggests that dietary factors modulate the development of colorectal cancer primarily during the later stages of promotion and progression (Bodmer, 1994, 1999). In this context, protective factors in the diet are probably at least as important as pro-carcinogens.

The influence of drugs and dietary components on the susceptibility of the colonic mucosa to neoplasia has been emphasized recently by the realization that use of non-steroidal antiinflammatory drugs (NSAID), such as aspirin and sulindac, is associated with a reduced risk of colorectal neoplasia. NSAID cause regression of precancerous colonic lesions in humans, suppress cell division and induce apoptosis in colorectal cancer cells in vitro. In parallel with the clinical interest in NSAID, the attention of nutritional scientists has been focused on the antimitotic and pro-apoptotic effects of the short-chain fatty acid (SCFA) butyrate, which is produced by bacterial fermentation of carbohydrate in the human colon. These, and other lines of investigation indicate that the modulation of programmed cell death cell by diet or pharmaceutical intervention may provide a route for the elimination of somatic mutations from the mucosal epithelial cells and thus help to suppress neoplasia (Ruemmele et al. 1999). In the present review, the characteristics of apoptosis in the colorectal mucosa are discussed, and the evidence that NSAID, butyrate and biologically active food components may inhibit colorectal neoplasia is critically appraised.

\section{The biology of programmed cell death}

Interest in the molecular mechanisms underlying programmed cell death has expanded hugely over the last decade, but the topic itself has a long and complex history. The distinct form of cell death now known as 'apoptosis' was probably first described by Virchow as early as 1859, in a treatise on the cellular pathology of tissue death (Virchow \& Chandler, 1859). Virchow noted that 'necrosis', in which the cell remained intact and visible following death, could be distinguished from 'necrobiosis' in which the cell shrank and vanished from viable tissue. It is 
arguable that the latter phenomenon was what we would now describe as apoptosis, though controversy about the precise distinction between necrosis and apoptosis continues to this day (Majno \& Joris, 1999). The earliest accounts of cell death were based on histological observations; Flemming (1885) used morphological characteristics to define a process he called 'chromatolysis'. This concept was employed by histologists for nearly 70 years (Graper, 1914; Glucksmann, 1951) but was eventually superseded, first by introduction of the term 'shrinkage necrosis' (Kerr, 1971) and shortly after by the concept of 'apoptosis', which is now recognized as a fundamental biological process of general importance in both normal development and pathophysiology (Kerr et al. 1972). Throughout this lengthy history, the classification of cell death was based on morphological criteria, and morphological assessment is still regarded as the 'gold standard' for the identification of apoptosis within tissues (Bellamy et al. 1995). Recent advances in biochemistry and molecular genetics have revolutionized the study of apoptosis, but a basic understanding of the process must begin with the structural changes that occur during cell death.

\section{Morphological aspects of apoptosis}

Apoptosis is typically a localized event affecting individual cells that are more or less widely dispersed within a tissue, whereas necrosis tends to occur in many adjacent cells simultaneously. Early in apoptosis the nucleus shrinks and becomes convoluted, and the chromatin aggregates at the periphery, in close juxtaposition with the nuclear membrane. In epithelial cells there is a more or less simultaneous loss of contact and communication with neighbouring cells. The microvilli disappear, often to be briefly replaced by irregular and rapidly changing smooth protuberances or 'blebs'. The endoplasmic reticulum becomes dilated, but the cytoplasm itself undergoes condensation, so that the organelles become crowded within the cell. Shortly afterwards the nucleus disintegrates into several densely-staining, membrane-bound bodies within the cytoplasm (Wyllie et al. 1980). A little later still, the irregular blebbing of the plasma membrane leads to the breakdown of the entire cell into discrete membranous packages, some of which contain degraded nuclear fragments. In epithelial tissues these 'apoptotic bodies' occupy the intercellular spaces, usually for only a short period before phagocytosis by adjacent cells, or by specialized cells of the immune system, which recognize and react to a range of markers on the surface of the apoptotic cell, including adhesion molecules and externalized phosphatidyl serine (Afford \& Randhawa, 2000). This process ensures that the dead cell is efficiently disposed of, and it probably also provides a pathway whereby the immune system is programmed to recognize pathogens responsible for the damage leading to initiation of cell death.

Although the early stages of apoptosis are accomplished within a few minutes, the apoptotic bodies taken up by phagocytes can be readily identified by classical morphological criteria in sections of wax-embedded intestinal mucosa (Potten, 1992) and in microdissected wholecrypt preparations (Latham et al. 1999) of the type used to quantify mitosis (Goodlad et al. 1991; Matthew et al. 1994). Only a small number of apoptotic events are visible in the 'snapshot' obtained from a single section or microdissected crypt taken from the healthy human or rodent intestinal mucosa, but because the process is so rapid, a few apoptotic remnants reflect a relatively high level of cell death (Bellamy et al. 1995). The morphological symptoms of apoptosis are the outward signs of the progressive, energy-dependent process in which intracellular macromolecules are systematically broken down, compartmentalized and sequestered by surrounding cells, so that leakage of pro-inflammatory cellular debris into the extracellular 
environment is minimized. Because all cells carry the essential machinery for their own destruction, their continued existence depends on a finely balanced system of pro- and antiapoptotic factors, the details of which have begun to emerge only recently.

\section{Biochemical mechanisms of cell death}

The fundamental importance of apoptosis in multicellular organisms is emphasized by the high degree of conservation that has occurred across phyla during evolutionary history. Much of the early work on the molecular mechanisms of apoptosis was carried out on the nematode Caenorhabditis elegans, in which 1090 somatic cells appear during hermaphrodite development, 131 of which must subsequently undergo programmed cell death (Sulston \& Horvitz, 1977). Ellis \& Horvitz (1986) identified a series of genes which are essential for apoptosis in $C$. elegans. One of these, ced-3, encodes a protein that facilitates cell death in the nematode, and bears strong sequence similarity to a human cysteine protease, interleukin-1 $\beta$-converting enzyme (ICE) (Yuan et al. 1993). It was also established that over-expression of the murine ICE gene in mammalian fibroblasts initiated apoptosis (Miura et al. 1993). Later work identified a series of fourteen related ICE-like proteases, many of which play a central role in the cell death pathway (Cohen, 1997). A uniform nomenclature has been developed for these proteases. The trivial name 'caspases' has been coined in which the initial 'c' signifies the fact that they are cysteine proteases and 'asp' denotes their site-specificity for aspartic acid residues. ICE is designated caspase- 1 because it was the first to be identified and the other members of the series are numbered in order of publication.

The caspases are present in cells as inactive zymogens requiring cleavage for their activation, often through the proteolytic activity of other caspases in the series. Thus they form a signalling cascade that transmits and amplifies the intracellular death signal, and mediates a complex range of intracellular events. Inactive caspase- 1 is a $45 \mathrm{kDa}$ protein, whereas the active enzyme comprises two catalytic subunits of $20 \mathrm{kDa}$ and $10 \mathrm{kDa}$. Activation involves cleavage of the pro-enzyme at four specific Asp-residues and removal of two smaller peptides with molecular weights of 11 and $2 \mathrm{kDa}$. Despite the seminal importance of its identification and isolation, caspase-1 appears to play a somewhat peripheral role in apoptosis in mammals. Caspase- $1^{-l-}$ knock-out mice have only relatively minor abnormalities of apoptosis (Kuida et al. 1995), but caspase-1 probably has other specific functions (Fadeel et al. 2000), including cytokine processing in inflammation. Caspase- 1 also appears to play a specific pro-apoptotic role in the central nervous system and it may be involved in induction of neuronal cell death following spinal injury (Li et al. 2000).

The key functions of the caspase signalling cascade, linking initiating stimuli from intraand extracellular sources to the downstream events of cell death, are summarized in Fig. 1. Caspase-3 appears to play a central role as one of the principal effector proteases in many mammalian systems. Its substrates are intracellular proteins and polypeptides that normally maintain the structural and functional integrity of the cell, so that in general their cleavage leads to disruption of survival pathways (Earnshaw et al. 1999). Unlike caspase-1-deficient mice, those lacking a functional caspase-3 gene die at 1-3 weeks of age, and show gross abnormalities of the central nervous system, symptomatic of impaired cell deletion during development. During the execution phase of cell death, caspase-3 cleaves a variety of proteins with a common aspartame-rich motif (Cohen, 1997). At the other end of the signal pathway, the initiator caspases are sensitive to a variety of stimuli including extracellular initiators of cell death such as tumour necrosis factor. The tumour necrosis factor receptor superfamily includes a variety of 


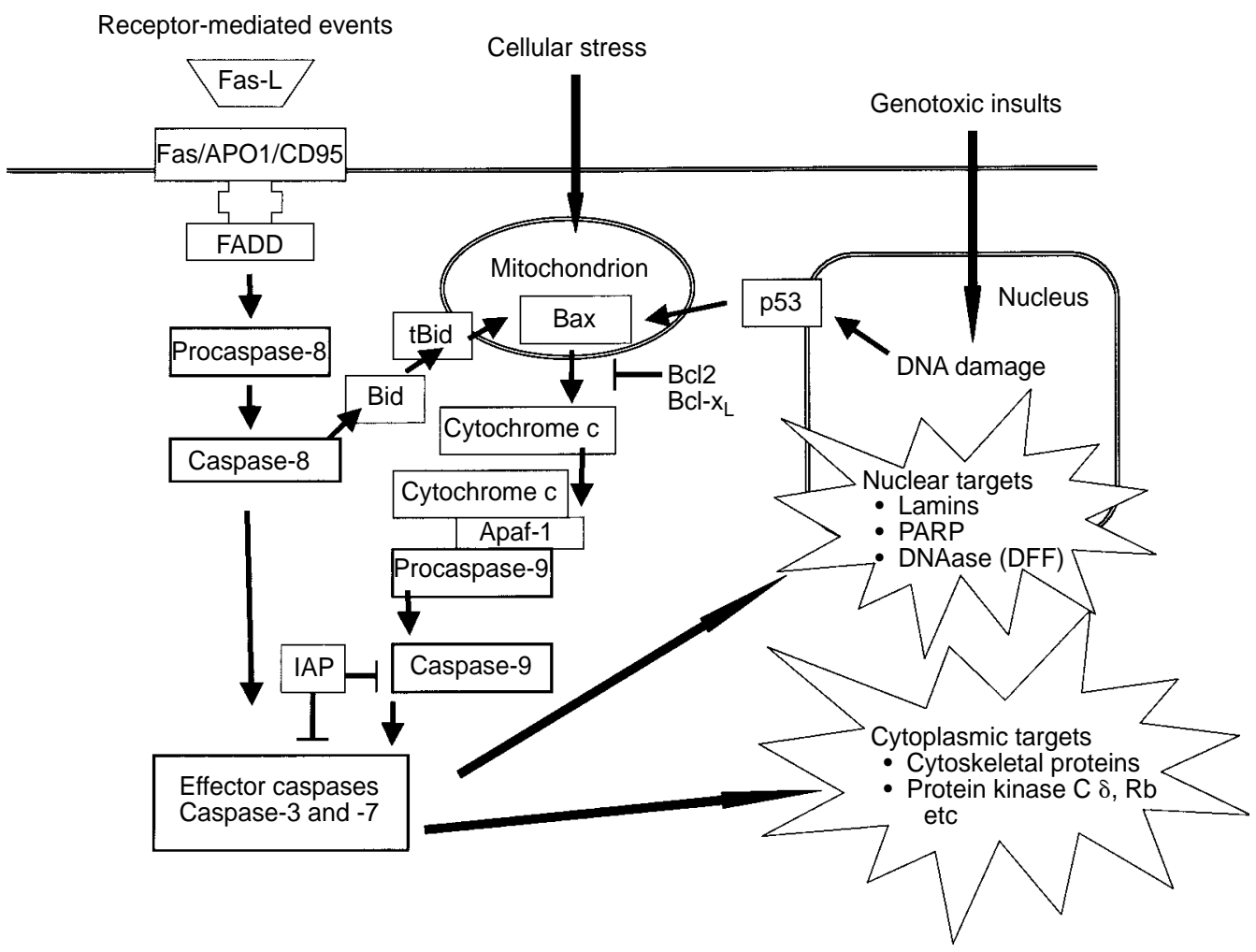

Fig. 1. A much simplified overview of the initiation and regulation of apoptosis. Two principal pathways of apoptosis are known, mediated via cell surface receptors (e.g. Fas/APO1/CD95 and the tumour necrosis factor family) and mitochondria respectively. Binding of the Fas ligand to its receptor triggers the formation of a complex comprising Fas-associated death domain (FADD) and the inactive zymogen procaspase-8. This initiates activation of caspase- 8 , which in turn activates the effector caspases -3 and -7 . The mitochondrial pathway is responsive to a variety of stimuli, including DNA-damaging agents, cytotoxic stresses, and the loss of extracellular growth factors. The pro-apoptotic protein Bax facilitates release of cytochrome $c$ from the mitochondrial inner membrane. The association of cytochrome c, apoptotic protease-activating factor 1 (Apaf-1) and procaspase-9 (the apoptosome) leads to activation of caspase-9, which then acts on effector caspases. Caspase-8 also activates the mitochondrial pathway via cleavage of Bid. Inhibitory regulators of apoptosis include Bcl-2 and Bcl- $\mathrm{X}_{\mathrm{L}}$, which suppress release of cytochrome $\mathrm{C}$, and proteins of the inhibitors of apoptosis (IAP) family, which are direct inhibitors of both initiator and effector caspases. PARP, poly(ADPribose) polymerase.

structurally related membrane receptors with multiple extracellular ligand-binding domains, elements spanning the plasma membrane, and a C-terminus region exposed to the cytoplasm. Activation of the receptor by an extracellular ligand (e.g. Fas) typically causes the cytosolic region to form a complex called a death domain. The Fas-associated death domain recognizes and binds procaspase- 8 molecules at a binding site called the death effector domain. The recruitment of procaspase- 8 molecules into close proximity initiates mutual activation by proteolytic cleavage, and enables them to initiate downstream events, including activation of caspase-3 (Muzio, 1998). Caspase-9 is another initiator caspase, strongly implicated in the induction of a second, stress-mediated apoptosis pathway, mediated via mitochondrial damage. In this sequence, pro-apoptotic stimuli cause the release of cytochrome $\mathrm{c}$ from the mitochondria 
into the cytoplasm where it forms a complex with apoptotic protease-activating factor 1 and procaspase- 9 (apoptosome). Caspase 9 is thereby activated, which enables it then to activate downstream caspases in a similar manner to caspase- 8 . The complexity and inter-relatedness of the system is illustrated by the fact that caspase- 8 also stimulates the release of cytochrome c from mitochondria by cleaving and activating Bid, a pro-apoptopic member of the Bcl-2 family (Kuwana et al. 1998; Yin, 2000). This mechanism can be regarded as a positive feedback loop that amplifies an initial weak caspase- 8 signal.

The activities of the caspase-mediated suicide pathway are regulated at many points by proteins that can stimulate or retard the process. For example the Bcl-2 protein family contains both pro- and anti-apoptotic factors (Adams \& Cory, 1998). Bcl-2 itself is a well-established inhibitor of apoptosis, that inhibits release of cytochrome c (Kluck et al. 1997), and competes with procaspase- 9 for apoptotic protease-activating factor 1 binding. Conversely the pro-apoptotic members of the Bcl-2 family, Bax and Bik, counteract the effects of Bcl-2 and similar proteins by binding and neutralizing them (Adams \& Cory, 1998). Another protein with strong affinity for the death effector domain of the Fas-associated death domain, called variously FLIP, Casper, I-FLICE and FLAME (Wallach, 1997), competes with procaspase-8 for Fas-associated death domain binding sites and acts primarily as an inhibitor of apoptosis, although it appears to be pro-apoptotic in some circumstances (Yeh et al. 2000). Finally, the highly conserved inhibitors of apoptosis family of proteins directly inhibit the proteolytic activities of the caspases -3, -7, and -9 (Deveraux et al. 1999).

The $p 53$ tumour suppressor gene encodes a transcription factor that functions as a focal point or hub in a number of cell signal pathways associated with regulation of both the cell cycle and programmed cell death (Vogelstein et al. 2000). Mutations affecting p53 are amongst the most commonly encountered in a range of human cancers, and loss of wild-type $p 53$ increases the susceptibility of rodents to induction of gastrointestinal cancers (Yamamoto et al. 2000). The precise role of $p 53$ in the regulation of programmed cell death is not yet entirely clear, but there is no doubt that it is crucial to the activation of at least some apoptotic pathways. Polyak et al. (1997) have observed patterns of p53 -dependent gene transcription in colorectal carcinoma cells, and shown that a high proportion of the genes activated by $p 53$ lead to the production of reactive oxygen species. They postulate that the resulting damage to mitochondria is the key stimulus for activation of caspases, and initiation of the apoptotic pathway (Fig. 1).

The complexity of the caspase system and its regulatory mechanisms reflects the requirement to initiate and amplify a cell death signal when required, but equally importantly, to maintain a stable system of checks and balances to regulate the fate of the cell in the face of conflicting pro- and anti-apoptotic signals. Understanding the behaviour of the system in the face of various pathological, nutritional or therapeutic stimuli is a considerable challenge. Recently a mathematical model, which describes the system in a manner that appears to be consistent with some recent experimental findings, has been described (Fussenegger et al. 2000).

\section{Cell proliferation and death in the crypt}

The small-intestinal crypts of the mouse are flask-shaped structures, approximately twenty cells in height and sixteen in circumference, containing around 250 cells in total (Potten \& Morris, 1988). The base of the murine small-intestinal crypt consists of approximately thirty fully differentiated Paneth cells whereas the colonic crypts, though somewhat larger than those of the small intestine, lack Paneth cells. At both sites, cell proliferation is most frequent near the base of the crypt, and virtually absent from the uppermost third, nearest the gut lumen. 


\section{Mitosis}

The dividing cells in the basal zone are of two types. Each stem cell undergoes asymmetric divisions, in which one daughter cell retains its physical location whilst the other daughter cell enters a population of dividing transit cells. These undergo several further symmetrical divisions as they and their progeny migrate away from the crypt base. All the cells derived from these transit divisions eventually cease to divide, and thereafter become fully differentiated. In the small intestine the stem cells are thought to lie immediately above the Paneth cell zone, whereas in the colon they are probably located at the very base of the crypt. Using a mathematical model of crypt cytokinetics, it has been estimated that small-intestinal crypts are likely to contain more than one but no more than six stem cells, and that these produce progeny that undergo six further divisions during migration (Potten \& Morris, 1988; Loeffler et al. 1993). It should be noted, however, that no histological techniques for the identification of crypt stem cells have been devised, and estimates of their number vary somewhat with the techniques used. Their precise numbers and location are therefore still uncertain (Cosentino et al. 1996).

In a series of elegant studies on the regeneration of crypts after exposure to increasing doses of radiation or cytotoxic drugs, it has been shown that small-intestinal crypts contain approximately six cells that readily undergo apoptosis in response to cytotoxic insults (Roberts \& Potten, 1994; Roberts et al. 1995). Whether or not these cells represent the ultimate stem cell population, eradication does not destroy the crypt because another group of six less-radiationsensitive cells, located at a slightly higher level, can take on stem cell characteristics and regenerate the crypt. The response to progressively higher doses of radiation suggests that, in total, around thirty of the newly formed dividing transit cells have the capacity for clonogenic reconstruction of the irradiated crypt, but the remaining 120 or so cells dividing at levels closer to the lumen do not retain this ability. The crypts of the colon are larger and contain more radiationresistant, slower cycling stem cells, but the location and numbers of potentially clonogenic crypt cells are similar (Cai et al. 1997).

\section{Apoptosis}

The highest rates of cell deletion from the colorectal mucosa occur at the surface, in the intercryptal zones, where senescent colonocytes are extruded into the gut lumen. Loss of adherence to the extracellular matrix induces apoptosis, a mechanism which has been termed 'anoikis' to emphasize its specialized link with epithelial exfoliation (Frisch \& Francis, 1994). Recent studies indicate that this pathway involves disruption of both cell-matrix interactions and intracellular signal pathways mediated by the protein focal adhesion kinase, which is selectively cleaved by caspases -3 and -6 during anoikis (Grossmann et al. 2001). Discrete apoptotic bodies, which typify the late stages of apoptosis before destruction of the cell remnants by phagocytes, are only observed in the basal regions of both the small- and large-intestinal crypts of rats and human subjects. However, evidence of apoptosis in the upper third of the normal mouse colonic crypt has been described (Kozoni et al. 2000), who used the terminal deoxynucleotidyl transferase-mediated deoxyuridine triphosphate biotin nick-end labelling (TUNEL) assay to delineate cells undergoing DNA cleavage. This illustrates the fact that the quantification, and even the definition of apoptosis in tissues can be method-dependent. Perhaps the TUNEL assay identifies the early events preceding exfoliation of mature colonocytes, although it would be somewhat surprising if DNA cleavage begins within the crypt.

A low level of p53-independent, 'background' apoptosis in the stem cell region of mouse small-intestinal crypts has been observed, and it has been proposed that this is an essential 
housekeeping function, serving to delete extra stem cells that may be formed from time to time by the symmetrical division of a parent stem cell (Potten, 1992; Bach et al. 2000). Such supernumerary stem cells would cause a significant imbalance in cell production, and hence lead to gross changes in crypt size and morphology. The basal level of p53-independent apoptosis is lower in the colon than in the small intestine of healthy mice (Merritt et al. 1994). This appears to be associated with the expression of the anti-apoptotic regulatory proteins Bcl-2 (Merritt et al. 1995), and the recently described Bcl-w (Pritchard et al. 2000), in the basal zones of the crypts.

Exposure to low doses of radiation, cytotoxic drugs or carcinogens induces a dose-dependent increase in apoptosis in the stem cell region of mouse small-intestinal crypts. This stressinduced response is absent in p53-null mice (Merritt et al. 1994). In normal animals it is spatially co-located with an increase in $p 53$ expression occurring a few hours after exposure (Merritt et al. 1994). A similar response occurs in the colon, but the dose-dependent threshold is higher, and the apoptotic zone extends toward the top of the crypt. It has been proposed that a greater sensitivity to genotoxic insults, together with the localization of the resulting apoptosis in the stem cell zone (Potten et al. 1992), makes the deletion of somatic mutations from smallintestinal crypts more efficient and accounts at least partially for the rarity of cancers of the small bowel (Merritt et al. 1995; Bach et al. 2000). This is a crucial hypothesis, which will be discussed in greater detail in the next section.

Treatment with the carcinogen 1,2-dimethylhydrazine (DMH) leads to a considerable increase in apoptosis, measured either morphologically (Latham et al. 1999) or by the TUNEL assay (Kozoni et al. 2000), in the basal region of rodent colorectal crypts. An abnormally high level of crypt cell apoptosis, which can be associated with a loss of epithelial integrity, is known to occur after treatment with 5-fluorouracil (Pritchard et al. 1998) and other drugs (Lee, 1993), and may also be involved in the pathophysiology of ulcerative colitis (Strater et al. 1997). There is a single report of a pathological condition in a primate (Macaca fascicularis) featuring chronic intractable diarrhoea, which was associated with high levels of apoptosis in the basal region of the colonic crypts (Rubio et al. 2001). The authors of the report coined the term 'apoptotic colonic disease' for this previously unreported disorder.

\section{The biology and molecular genetics of colorectal cancer}

The simplest concept of carcinogenesis is the three-stage model consisting of initiation, promotion and progression. At the initiation stage, a single cell is assumed to acquire a point mutation that remains unrepaired and confers some growth advantage. Successive cellular divisions then occur which enable the new mutated clone to proliferate at the expense of surrounding cells, thereby forming a focal lesion. During the promotion stage, the normal constraints on proliferation and spatial organisation within the affected tissue are disrupted still further, and these derangements are associated with the acquisition of further mutations. Colorectal carcinoma has provided many valuable insights into the origins and development of cancers in general, partly because of the easy access to the colonic lumen that can be achieved using flexible colonoscopy, and partly because of the existence of well-defined inherited syndromes, which provide insights into the more common, sporadic form of the disease (Kinzler \& Vogelstein, 1996).

The generally accepted model for the origin and development of sporadic colorectal carcinomas is the adenoma-carcinoma sequence (Winawer, 1999). According to this hypothesis, most, if not all, human colorectal carcinomas begin as non-invasive adenomatous polyps that 
develop and become malignant over 10 to 20 years, largely in response to environmental factors (Hill et al. 1978). Populations with a high prevalence of adenomas also have a high incidence of colorectal cancer, and individuals who harbour polyps have a higher risk of developing cancer than individuals with no previous history of polyps. In many western industrialized countries polyps are very common, and up to $50 \%$ of the middle-aged male population are affected. The transition from non-invasive adenoma to an invasive carcinoma is a relatively rare event, but the high frequency of polyps in the otherwise healthy population means that screening and polypectomy provide an effective means of prevention (Markowitz \& Winawer, 1999). The causal link between non-invasive polyps and cancer is further emphasized by the example of familial adenomatous polyposis (FAP), an inherited disease in which patients acquire hundreds of polyps in the colon and rectum early in life, and almost invariably go on to develop colorectal carcinoma before middle-age. There is some controversy as to whether animal models of colorectal carcinoma provide convincing experimental support for the adenoma-carcinoma sequence (Maskens \& Dujardin-Loits, 1981), but much of this debate appears to be based on the misinterpretation of pathological findings (Wright \& Alison, 1984).

The major breakthrough in our understanding of the mechanisms underlying the adenoma-carcinoma sequence came with the discovery that the developmental stages of the disease are associated with the acquisition of somatic mutations affecting proto-oncogenes or tumour suppressor genes (Vogelstein et al. 1988). The precise order in which the mutations occur varies greatly between individual patients but some generalizations are possible. In most series, around $50 \%$ of colorectal carcinomas are found to have a mutation in the $K$-ras protooncogene. Vogelstein et al. (1988) examined 172 colorectal tumours at various stages of development and observed ras mutations in $47 \%$ of carcinomas, and in $58 \%$ of adenomas larger than $1 \mathrm{~cm}$ in diameter, but they occurred in only $9 \%$ of adenomas less than $1 \mathrm{~cm}$ in diameter (Vogelstein et al. 1988). Similar size dependence was observed for other mutations, leading to the conclusion that the acquisition of mutations occurred in parallel with the growth and progression of the tumour. Mutations in the tumour suppressor gene $p 53$, though very common across the whole clinical spectrum of human cancers (Soussi, 2000), are rare in small adenomas, and their appearance appears to be associated with the transition to a carcinoma (Gafa \& Lanza, 1998).

The widespread acceptance of the somatic mutation model for the development of colorectal cancer has prompted studies to identify the crucial genetic changes associated with the transition from normal mucosa to neoplastic lesion. The earliest identifiable precancerous lesions of the colonic mucosa are aberrant crypt foci (ACF) (Pretlow et al. 1991). These structures are visible under low power microscopy in methylene blue or Feulgen's stained mucosal tissue, and are characterized by their enlargement, thickened epithelial layers, and slightly raised pericryptal region. They occur in the colonic mucosa of human patients in association with adenomatous polyps or carcinoma, and they are also the earliest lesions to appear in rodents after treatment with colorectal carcinogens, including DMH, azoxymethane and Phipp. Although their usefulness as quantitative predictors of tumour numbers in animal models has been disputed (Hardman et al. 1991), ACF are now widely regarded as early biomarkers of neoplastic changes during colorectal carcinogenesis (Roncucci et al. 2000). Several groups have reported the presence of $K$-ras mutations in ACF induced in rodents treated with azoxymethane (Shivapurkar et al. 1994), and in sporadic ACF from resected human colon (Smith et al. 1994). Somatic mutations of the APC gene have also been detected in ACF from human colon (Smith et al. 1994), but they seem to be acquired at a later stage of chemically induced neoplasia in rodent models (De Filippo et al. 1998).

Using a different approach to the problem of identifying the type and minimum number of 
mutations necessary for the growth of early adenomas, Lamlum et al. (2000) recently screened 210 small $(0 \cdot 3-10 \mathrm{~mm})$ adenomatous polyps, obtained from patients with FAP, for mutations to selected loci including $A P C, K$-ras and $\beta$-catenin, and for allelic losses and microsatellite instability (Lamlum et al. 2000). Mutations other than to the APC loci were rare, and the authors concluded that in both familial and sporadic adenomas, two mutations at the APC locus are sufficient to enable the lesions to grow to about $1 \mathrm{~cm}$ in diameter with mild dysplasia. It is generally accepted that APC mutations are in most cases the 'gatekeepers' of colorectal neoplasia, though in some tumours, other mutations may be involved. The important point is that the critical mutation must confer some advantage on the affected cells, placing them under selective pressure to survive and grow at the expense of normal cells in the surrounding tissue (Tomlinson \& Bodmer, 1999).

Another important but unresolved issue concerning the pathogenesis of colorectal tumours is that of the precise anatomical site of the precursor cell that acquires the crucial mutations and undergoes clonal expansion to form the initial dysplastic lesion. Since the stem cells at the base of the crypt are adapted to continue dividing in situ, it is generally assumed that they are the crucial tumorigenic precursor cells (Bach et al. 2000). However this has never been conclusively proved. A recent study by Shih et al. (2001) shows that in small human adenomas, dysplastic cells containing APC mutations are located in the surface epithelium at the top of the crypt, whilst the basal cells contain genetically distinct, non-dysplastic cells. This suggests that the progenitor cells giving rise to the neoplastic clone may have migrated from the crypt base, or arisen spontaneously in the mature cell population of the surface epithelium, and then somehow evaded deletion via the anoikis pathway. The resolution of this issue will require much more detailed information on the early morphological changes associated with the transition from a flat mucosa to a focal lesion.

The precise nature of the driving forces for tumour growth at each stage of the adenoma-carcinoma sequence remains a matter for debate. Loeb (1998) has argued that the rate of mutation is a crucial factor in the pathogenesis of a neoplastic phenotype, that cancer cells contain far more mutations than can be accounted for by random mutation in proliferating cells, and that the driving mechanism for tumour development is the appearance of a 'mutator phenotype' early in tumorigenesis, coupled with selection pressure for mutations conferring a growth advantage (Loeb, 1998). There is little doubt that a high mutation rate is a characteristic feature of many types of cancers, as is illustrated by the instability of the repetitive genetic elements known as microsatellites, which are frequently detected in tumours (Loeb, 1994). However Tomlinson et al. (1996) have argued that a high mutation rate does not in itself cause a tumour to grow, and that the selective advantage of particular mutations is of overwhelming importance. Both sides of this debate point to the role of DNA mismatch repair genes ( $h M L H 1$, $h M S H 2, h P M S 1, h P M S 2$, GTBP/hMSH6) which are known to be involved in the pathogenesis of many cancers, including those of the alimentary tract (Wheeler et al. 2000).

Amongst the first hereditary cancers to be identified were the Lynch syndromes (Lynch \& Krush, 1971), now renamed hereditary non-polyposis colorectal cancer to distinguish the condition from FAP (Lynch \& Krush, 1971). The condition is now known to result from germline mutations at DNA mismatch repair loci, and probably accounts for less than $10 \%$ of all colorectal cancers. Patients with mutations in $h M L H 1$ or $h M L H 2$ have an approximately $80 \%$ lifetime risk of colorectal cancer but unlike FAP patients who may have thousands of adenomatous polyps, hereditary non-polyposis colorectal cancer patients do not acquire more polyps than the general population. Tomlinson \& Bodmer (1995) have used mathematical models to show that tumours grow because of selection for mutations conferring a growth advantage, which is often manifested by a failure of the normal pathways of cell differentiation or death. Successive 
mutations of this type can lead to incremental increases in the population of non-invasive cells, and once the new population size is established the lesion can remain quiescent for an extended period before another mutation occurs. Only at the final stage of the process does a transition occur to the exponential growth rates of a mature invasive cancer. This is precisely the behaviour of tumours at successive stages of the adenoma-carcinoma sequence. Support for this general model is provided by recent studies showing that over-expression of $h M S H 1$ and $h M S H 2$ genes induces apoptosis in cells, regardless of their DNA repair capacity (Zhang et al. 1999). This suggests that suppression of apoptosis may be an additional procarcinogenic effect of these mutations in hereditary non-polyposis colorectal cancer. Thus although a high rate of mutation undoubtedly increases likelihood of procarcinogenic mutations appearing, it is the effect of such mutations on the phenotype, particularly in so far as they affect the initiation and control of cell death, that appears to be a crucial factor at every stage of tumour development.

\section{Mitosis, apoptosis and cancer}

One of the central dogmas of the somatic mutation theory of carcinogenesis is that a high rate of mitosis in an otherwise healthy tissue increases its vulnerability to mutagenesis, and therefore to the development of cancer (Barthold \& Beck, 1980; Preston-Martin et al. 1990). DNA is intrinsically more vulnerable to damage during cell replication, and in a rapidly proliferating cell population there is, in theory, less time available for DNA repair (Tong et al. 1980; Ames \& Swirsky Gold, 1991). Moreover, frequent cell divisions increase the probability of somatic recombination occurring, so that that cells heterozygous for a tumorigenic mutation can become homozygous (Groden et al. 1990). Although there is much evidence to support the hypothesis, it has been disputed vigorously (Farber, 1995), and has proven very difficult to test definitively. The complexity of this problem is illustrated by a recent report on mutagenesis in an in vitro model, in which active proliferation was shown to be essential not only for the appearance of mutations, but also for DNA repair, which contrary to the authors' expectations, did not occur in quiescent cells (Bielas \& Heddle, 2000).

Genetic analysis of human colorectal tumours provides strong evidence that most are clonal, and therefore derived from a single mutated epithelial cell (Fearon et al. 1987). In principle the target cell could be either a stem cell or a dividing transit cell, but since stem cells are specialized to remain fixed within the crypt, it is generally assumed that these are the target cells most likely to give rise to a new clonal population bearing a potentially tumorigenic somatic mutation. Stem cells have a cycle-time roughly twice as long as their progeny in the dividing transit population (Potten, 1986). Heddle et al. (1996) have pointed out that, on theoretical grounds, the existence of a distinct stem cell population in self-renewing tissues is not absolutely necessary. The hierarchy of replicating cells in the crypt may therefore be an evolutionary adaptation to protect the tissue from somatic mutations by reducing the number of potentially vulnerable cell divisions, and increasing the time available for DNA repair, or for the self-destruction of irretrievably damaged cells (Heddle et al. 1996).

If the cytokinetic peculiarities of the stem cell population provide a first line of defence against somatic mutations of the intestinal epithelium, DNA repair and apoptosis can be regarded as two further strategies deployed by the tissue for the protection of its genome (Wyllie et al. 1999). The fact that these functions are intimately linked at a mechanistic level is illustrated by the fact that the DNA-repair genes $M S H 2$ and $M L H 1$ have both been implicated in the regulation of apoptosis (Zhang et al. 1999). Complete loss of $M S H 2$ greatly increases the 


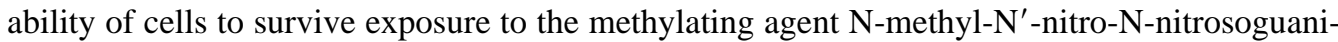
dine in vitro (de Wind et al. 1995). Furthermore, studies with MSH2 knockout mice have established that this gene is essential to the wave of apoptosis in the crypts of the small intestine following exposure to $\mathrm{N}$-methyl- $\mathrm{N}^{\prime}$-nitro-N-nitrosoguanidine in vivo (Toft et al. 1999). This strongly suggests that loss of $\mathrm{MSH} 2$ compromises both the repair of mutations in the intestinal epithelia, and their deletion from the tissue via apoptosis.

Thus crypt cell apoptosis seems likely to be an essential defence against the appearance of somatic mutations that constitute the earliest steps in tumorigenesis. At later stages in the adenoma-carcinoma sequence, mutations or gene-silencing events that cause an inhibition of apoptosis are thought to be critical for the survival and growth of tumours (Bodmer, 1999). Such genetic and epigenetic mechanisms may affect a host of different components of the apoptotic signal pathway, including the caspases themselves. For example it has recently been reported that human colon cancer cells exhibit down regulation of caspases -7 and -9 , relative to normal mucosa on the same tissue section (Palmerini et al. 2001). Endogenous or environmental factors causing high levels of mitosis and suppression of apoptosis are probably risk factors favouring progression at every stage of the adenoma-carcinoma sequence. Conversely, drugs or other agents that can inhibit crypt cell mitosis and lower the threshold for apoptosis might be expected to delay progression, slow the growth of established lesions and perhaps even cause their regression. Evidence in favour of this mechanism comes from recent studies on the chemopreventive effects of NSAID.

\section{Non-steroidal anti-inflammatory drugs and colorectal neoplasia}

Interest in the inhibitory effects of NSAID against colorectal neoplasia was first prompted by the results of animal studies in which the drug indomethacin was shown to suppress tumours induced with DMH by up to $40 \%$ (Pollard \& Luckert, 1980). Waddell et al. (1989) later confirmed the relevance of this finding for human disease by showing that treatment with another NSAID, sulindac, substantially reduced, and in some cases entirely eliminated, polyps in a small group of patients suffering from FAP. A significant reduction of around $50 \%$ in the incidence or mortality from colorectal cancer was subsequently detected in three out of four epidemiological studies conducted on regular users of aspirin (Lancaster \& Silagy, 1994), though it must be noted that one major intervention study has failed to confirm this effect during 5 years of follow-up (Gann et al. 1993). Whatever the practical role of aspirin and other NSAID in the prevention of colorectal cancer may turn out to be, the evidence that these compounds suppress the growth of tumours in animal models and cause regression of precancerous lesions in man seems strong and consistent. In one particularly interesting study, Takayama et al. (1998) used sequential endoscopies to study the effects of sulindac on ACF in human subjects and showed marked reductions, and in some cases complete eradication, of these lesions in patients treated with sulindac.

If a tumour is to grow it is necessary for the rate of cell birth to exceed that of cell loss (Tomlinson \& Bodmer, 1995), but this does not imply that cancer cells are entirely resistant to the induction of apoptosis. Indeed, although colonic tumours do exhibit rapid cell proliferation, a high rate of apoptosis has also been observed in various types of colorectal adenomas and carcinomas (Partik et al. 1998). The regression of colorectal lesions induced by treatment with NSAID provides strong circumstantial evidence that the effect of these drugs is to arrest cell growth, or stimulate apoptosis, or possibly both, and this interpretation is supported by experimental studies. It is now well established that aspirin and other NSAID can arrest the cell cycle 
and induce apoptosis in colorectal carcinoma cell lines in vitro (Piazza et al. 1995; Shiff et al. 1995; Elder et al. 2000), and there is increasing evidence that this is the principal mechanism whereby they cause regression of polyps and ACF in the human colon (Pasricha et al. 1995; Stoner et al. 1999; Reinacher-Schick et al. 2000).

The classical biochemical function of aspirin and other NSAID is inhibition of cyclooxygenase (prostaglandin $\mathrm{H}$ synthase) activity, leading principally to a reduction in prostaglandin synthesis (Vane \& Botting, 1998). There are two known cyclo-oxygenase isoforms (COX-1 and COX-2). COX-1 is constituitively expressed in most mammalian tissues, where it plays a fundamental 'housekeeping' role in the regulation of cellular function. COX2 shares approximately $62 \%$ amino acid homology with COX-1, but differs greatly in its expression pattern and function. In most tissues COX-2 is virtually undetectable until induced by mitogens, including tumour promoters and pro-inflammatory cytokines. Under these conditions COX-2 expression generates prostaglandins that differ from those produced by COX-1, both in their effects, and in their subcellular localization. COX-2 is therefore regarded as an immediate-early gene, with functions linked to long-term cellular responses including cell differentiation and proliferation. COX-2 is also expressed in cancer cells of various types. In the case of colorectal tumours the level of expression depends on the stage of development, so that whereas only a small proportion of adenomatous polyps express COX-2, it is detectable in about $90 \%$ of carcinomas (Eberhart et al. 1994; Kargman et al. 1995; Sano et al. 1995). Inhibition of COX-2 is central to the therapeutic function of aspirin and other NSAID, and the unwelcome side-effects of these drugs are primarily due to the simultaneous inhibition of COX-1. This has prompted the development of a range of selective COX-2 inhibitors.

Given the well-defined pharmacological activity of the NSAID it would be natural to assume that their ability to inhibit proliferation and induce apoptosis in tumour cells was a consequence of COX-2 inhibition. Initial studies seemed to confirm this hypothesis. Overexpression of COX-2 in rat intestinal epithelial cells was shown to be associated with increased adherence to the substrate, elevation of bcl-2 expression and inhibition of apoptosis, all of which were reversed by treatment with sulindac sulfide (Tsujii \& DuBois, 1995). Recent studies have confirmed that treatment with the specific COX-2 inhibitor celecoxib for 6 months reduced the numbers of polyps in FAP patients by around $30 \%$ (Steinbach et al. 2000). However in vitro studies have shown that the pro-apoptotic effects of NSAID are independent of COX-2 expression in various systems (Smith et al. 2000a). Alternative models for the effects of sulindac have been proposed, including direct induction of apoptosis by disruption of the mitochondrial inner membrane (Waddell, 1998), modification of arachidonic acid metabolism (Chan et al. 1998), or direct modulation of members of the Bcl family of regulatory proteins (Marx, 2001).

\section{Dietary factors, crypt cytokinetics and colorectal neoplasia}

NSAID or related compounds may eventually be used to provide safe and effective chemopreventive agents for the control of colorectal cancer in high-risk groups. However this rapidly developing field is relevant to the wider context of human nutrition because it establishes the principle that factors modulating the balance of cell birth and death in the colonic epithelium can modify the initiation and progression of cancer. In this section, evidence for the existence of biologically active components of food that can suppress colorectal carcinogenesis by increasing apoptosis in the colorectal epithelium is reviewed. 


\section{Butyrate}

SCFAs are the major products of carbohydrate fermentation in both the rumen and the nonruminant colon. Acetate, propionate and butyrate account for about $90 \%$ of SCFA in the human large bowel. Of these, butyrate provides around $25 \%$ of the total, and it is usually present at a concentration of approximately $25 \mathrm{~mm} / \mathrm{kg}$ faecal material in the proximal human colon (Cummings et al. 1987). It is estimated that $95 \%$ of the SCFA produced in the human large bowel is absorbed and metabolized, and it is well established that butyrate in particular functions as a metabolic substrate for the colonic epithelial cells in vivo (Roediger 1990). Perfusion of the intact colon with a butyrate solution close to physiological concentrations stimulates crypt cell proliferation in rats (Sakata \& von Engelhardt, 1983; Kripke et al. 1989). When animals with a conventional colonic microflora are fed fermentable forms of dietary fibre they have a faster crypt cell proliferation rate than animals fed a fibre-free diet, but this effect is absent in germ-free animals that cannot produce butyrate by fermentation (Goodlad et al. 1987; Pell et al. 1995). Instillation of SCFAs into the human rectum also exerts a trophic effect on the mucosa (Mortensen et al. 1991). It has been proposed that two forms of inflammatory bowel disease, diversion colitis and ulcerative colitis, result from an absence or failure of normal butyrate metabolism, and there is experimental evidence for an anti-inflammatory effect of butyrate enemas in human subjects (Harig et al. 1989; Mortensen \& Clausen, 1996).

Clearly there is a strong case to be made for butyrate as a nutrient, and as a trophic substrate for the colonic mucosa, but recently attention has switched to its effects on tumour cell differentiation, growth kinetics and death. The ability of butyrate to inhibit the growth and induce a more differentiated phenotype in a variety of different tumour cells has been recognized for a number of years (Hagopian et al. 1977; Augeron \& Laboisse, 1984; Barnard \& Warwick, 1993). More recently Hague et al. (1993, 1995) and others (Heerdt et al. 1994) demonstrated that exposure to butyrate at physiologically relevant concentrations induced apoptosis in human colorectal adenoma and carcinoma cell lines. This phenomenon prompted the suggestion that the increased intra-colonic butyrate levels associated with colorectal fermentation of polysaccharides might favour apoptosis of neoplastic epithelial cells in vivo, and hence account for the protective effects of fibre-rich diets (Hague et al. 1993).

The mechanism of butyrate-induced apoptosis is the subject of intense current interest. It has been demonstrated that, like $\gamma$ irradiation (Bracey et al. 1995), butyrate readily induces apoptosis in human colorectal tumour cells despite the absence of a functional p53 pathway (Hague et al. 1993). The mechanism is caspase-dependent (Chai et al. 2000), and apparently involves signal transduction via the Fas-ligand death receptor (Chapkin et al. 2000). The transcriptional activation of the Bax gene via the c-Jun N-terminal kinase signal pathway has recently been implicated in the induction of apoptosis by butyrate in DiFi and FET human colorectal carcinoma cells (Mandal et al. 2001).

There is increasing evidence that the primary pro-apoptotic effect of butyrate may be inhibition of the enzyme histone deacetylase, leading to hyperacetylation of histones (Siavoshian et al. 2000; Wu et al. 2001). Modulation of histone acetylation alters gene transcription directly, and may facilitate the expression of pro-apoptotic genes that are normally silenced. In a recent study, Della Ragione et al. (2001) used cDNA microarrays to observe such changes in the expression of twenty-three genes in colorectal tumour cells treated with butyrate, and with the histone deacetylase inhibitor trichostatin A. Although the great majority of such mechanistic studies on the pro-apoptotic effects of butyrate have been carried out in vitro, there is some interesting evidence that a diet rich in wheat bran promotes histone acetylation of rat colonic epithelial cells in vivo (Boffa et al. 1992). 
There is continuing uncertainty about the dual role of butyrate as a source of energy, and as a potent modifier of gene expression. Hass et al. (1997) examined the effect of butyrate on viable sheets of mucosal cells obtained from guinea pig colon in vitro. In the absence of butyrate they observed high levels of epithelial cell apoptosis, associated with increased expression of the gene Bax. This apparent paradox is probably a reflection of the importance of butyrate as a metabolic substrate. Singh et al. (1997) have shown that the effect of butyrate on cultured cell lines depends critically on the availability of other energy sources. In the absence of glucose and pyruvate, both adenoma and carcinoma cells showed increased apoptosis, but this was reversed by the addition of low concentrations of butyrate. In contrast, the same concentrations of butyrate induced apoptosis under energy-replete conditions. The problem of translating such in vitro studies to the intact gut is heightened by the fact that malignant transformation increases the energy requirements of the cell, but the implications of this have not been explored in vivo.

The general hypothesis that dietary fibre protects against cancer by generating intraluminal butyrate has recently begun to receive experimental support from in vivo studies. In previous studies, relatively poorly fermented substrates such as wheat bran have tended to inhibit carcinogenesis more effectively than fermentable substrates but it has recently been reported that maintenance of a stable butyrate environment in rats fed resistant starch or fructooligosaccharides is associated with reduced numbers of ACF (Perrin et al. 2001). Caderni et al. (1998) used slow-release pellets to expose the rat colonic epithelium to butyrate, and reported increased apoptosis, but no protective effect against azoxymethane-induced neoplasia (Caderni et al. 1998, 2001). However Avivi-Green et al. $(2000 a, b)$ have described increased expression of pro-apoptotic signal proteins, an increased crypt apoptotic index, and suppression of chemically induced neoplasia in rats fed a fermentable type of fibre, and in those treated directly with butyrate by intra-colonic instillation (Avivi-Green et al. 2000a,b). This work stands in sharp contrast to earlier studies, which described strong pro-carcinogenic effects of fermentable polysaccharides in an animal model (Jacobs \& Lupton, 1986).

Experiments with human subjects have been hampered by the difficulty of manipulating the SCFA content of the colorectal lumen with any degree of precision. In one study, Kashtan et al. (1992) set out to explore the effect of soluble fibre derived from oat bran on faecal SCFA and mucosal markers of crypt cell proliferation in a group of volunteers, with or without a history of adenomatous polyps. Two groups were given dietary supplements $(16.4 \mathrm{~g} / \mathrm{d})$ of either oat bran or wheat bran for 2 weeks. Oat bran is rich in $\beta$-glucan, a soluble form of dietary fibre that is more readily fermentable by colonic micro-organisms than the lignified insoluble polysaccharides of wheat bran (Lund \& Johnson, 1991). Consumption of oat bran was associated with a significant decrease in faecal $\mathrm{pH}$, but faecal SCFA and butyrate levels actually fell in the oat-bran group by an amount that approached statistical significance. Apoptosis was not measured, but there was no significant effect of either supplement on the crypt cell labelling index of rectal biopsies obtained before and after the dietary intervention.

In a recent placebo-controlled intervention study, a dietary supplement of ispaghula husk $(3.5 \mathrm{~g} / \mathrm{d})$ was given to patients with a history of adenomatous polyps to determine the effect on adenoma recurrence after 3 years (Bonithon-Kopp et al. 2000). The study was not designed to test any particular mechanistic hypothesis, and no attempt was made to determine either faecal butyrate levels or the rate of apoptosis. The outcome was a modest but statistically significant increase in the risk of adenoma recurrence in the isphagula-supplemented group. Given the limited physiological information available it is difficult to account for this finding, but one speculation is that supplementation with certain fermentable types of fibre leads to increased crypt cell proliferation, as previously observed in animal models (Jacobs \& Lupton, 1986). Faster cell 
proliferation with no compensating increase in apoptosis might increase the growth of microscopic lesions. This study probably says little about the effects of fibre-rich diets based on high levels of fruits and vegetables. However dietary supplements containing soluble, highly fermentable polysaccharides from unconventional sources should perhaps be treated with caution until more is known about their effects on proliferating crypt epithelial cells in the intact human gut (Wasan \& Goodlad, 1996).

\section{Polyunsaturated fatty acids}

In contrast to the SCFAs, long-chain fatty acids derived from dietary fat function as structural components of cell membranes as well as metabolic substrates. Dietary triacylglycerols are hydrolysed to their component fatty acids during digestion and then re-esterified, before transport and metabolism, or storage in adipose tissue. The proportion of total dietary energy derived from lipids varies considerably between populations, and the extent to which this contributes to geographical differences in the prevalence of cancer has been a focus of interest for nutritionists for many years (Hursting et al. 1990). The role of total fat intake as a determinant of cancer is outside the scope of the present review, but there is growing interest in the significance of specific fatty acids in relation to the growth and metabolism of tumour cells, and much of this new evidence may be relevant to the biology of apoptosis in the intestinal mucosa.

There is some epidemiological evidence to suggest that diets high in marine oils are associated with a reduced risk of colorectal cancer (Hursting et al. 1990; Schloss et al. 1997), and that dietary supplementation with purified fish oils rich in eicosapentaenoic acid (EPA) and docosahexaenoic acid (DHA) can suppress colorectal crypt cell mitosis in human subjects (Anti et al. 1994). The relationship between fat consumption and carcinogenesis in animal models is complex. For example, it has been known since the 1950s that a high fat intake accelerates the development of murine mammary tumours (Tannenbaum \& Silverstone, 1953), but more recent studies have made it clear that the effect depends upon the fatty acid composition of the diet. In general polyunsaturated fatty acids (PUFA) of the $n-6$ series, such as linoleic acid, promote the induction of mammary tumours more than saturated fats, monounsaturated fatty acids are largely without effect, and $n-3$ PUFA such as EPA and DHA are weakly protective (Fay et al. 1997). Similarly, induction of tumours with azoxymethane is increased during the postinitiation phase by diets rich in $n-6$ PUFA, but not by diets containing a high proportion of $n-3$ PUFA derived from fish oil (Reddy, 1992).

The contrasting effects of different PUFA on tumour growth in vivo seem to be consistent with their effects on tumour cells in vitro. It has been clear for some time that certain essential fatty acids, notably $\gamma$-linolenic acid, arachidonic acid, EPA and DHA are selectively toxic to tumour cells. Using a co-culture technique, Begin et al. $(1986,1986)$ observed that human cancer cells outgrew normal fibroblasts in the absence of essential fatty acids but in the presence of PUFA the effect was reversed so that the tumour cells were at a disadvantage. Das (1991) demonstrated that the inhibition of tumour cell proliferation in the presence of $\gamma$-linolenic acid, arachidonic acid and EPA was caused by selective cytotoxicity, and that cell death was blocked by antioxidants, enhanced by pro-oxidants and proportional to the degree of peroxidation induced in the cells. More recent studies have confirmed these findings, extended them to other cell lines and shown that apoptosis plays an important role in the cytotoxicity induced by PUFA (Finstad et al. 1998; Hawkins et al. 1998; Ramesh \& Das, 1998). In the human colorectal adenocarcinoma cell line HT29, incubation with EPA leads first to detachment of the cells from the substratum, followed by apoptosis, which can be enhanced by depletion of intracellular 
glutathione levels (Latham et al. 1998), and blocked with antioxidants and caspase inhibitors (Clarke et al. 1999).

Dietary intake of long-chain fatty acids exerts important effects on crypt cytokinetics in vivo. In the rat, replacing maize oil with fish oil in a semi-synthetic powdered diet leads to a reduction in crypt cell mitosis (Pell et al. 1994). However Chang et al. (1997), whilst confirming the protective effects of fish oil, compared with maize oil, in a rat-azoxymethane model of colorectal carcinogenesis, reported that this effect was more closely correlated with increased crypt cell apoptosis than with suppression of mitosis. Exposure to DMH metabolites leads to the induction of DNA methyl adducts, including O6-methylguanine (James \& Autrup, 1983), and this is associated with the arrest of mitosis and induction of $p 53$-dependent apoptosis in the lower half of the crypt. Latham et al. (1999) fed rats on a semi-synthetic basal diet containing maize oil $(80 \mathrm{~g} / \mathrm{kg})$ before treatment with the specific colorectal carcinogen $(\mathrm{DMH})$ or a sham injection. Immediately after the injections the groups were subdivided; half continued on the control diet and half were transferred to diets in which the maize oil was replaced with fish oil (97\% triacylglycerol; $19 \%$ EPA; $8 \%$ DHA), and animals were killed after $24 \mathrm{~h}$ and $48 \mathrm{~h}$. In rats fed fish oil with no DMH treatment there were statistically significant increases in apoptosis and reductions in mitosis after $48 \mathrm{~h}$. In the rats treated with DMH there was the expected increase in apoptosis, but this response was more than doubled in those treated with both DMH and fish oil. In a second experiment, rats were treated with DMH on two occasions at weekly intervals to induce ACF. After receiving the injections, both the treatment group and a shaminjected control group were switched to the fish-oil diet for $48 \mathrm{~h}$. After 18 weeks the frequency of ACF was significantly lower in the animals fed fish oil compared with the controls. These results are consistent with the hypothesis that fish-oil consumption caused enhanced levels of apoptosis during the phase of DNA damage following exposure to $\mathrm{DMH}$, and this led to greater deletion of cells otherwise destined to form precancerous lesions.

The precise mechanism by which $n-3$ PUFA trigger apoptosis in intestinal epithelial cells is not yet established. Under in vitro conditions, the increased cell death brought about by treatment with EPA is considerably amplified by depletion of cellular glutathione and blocked by antioxidants (Clarke et al. 1999; Latham et al. 2001). This suggests that the effect of incorporating $n$-3 PUFA into the cellular lipid pool is to increase the production of reactive oxygen species, which are known to induce apoptosis in a number of different cell lines (Antunes \& Cadenas, 2001). A similar mechanism has been proposed to account for the induction of apoptosis in a human adenocarcinoma line by $\beta$-carotene (Palozza et al. 2001). A role for reactive oxygen species in the induction of colonic epithelial cell apoptosis in vivo is suggested by the fact that induction of apoptosis by dietary fish oil in the intact rat colon is also enhanced by depletion of glutathione (Latham et al. 2001). These observations do not rule out the involvement of other mechanisms, including perhaps an effect of the composition of the cellular lipid pool on prostaglandin metabolism.

\section{Flavonoids}

The flavonoids are a large and complex group of phenolic compounds that contribute to the flavour and colour of vegetables and fruits, and account for most of the dissolved solids in beverages such as tea, coffee and wine. All the flavonoids possess a three-ring structure containing two aromatic centres (rings A and B) and a central oxygenated heterocycle (ring C). The total intake of flavonoids in the human diet has been estimated to be as high as $1 \mathrm{~g} / \mathrm{d}$ in the USA, but this is almost certainly an overestimate based on inadequate analytical data. Hertog et al. 
(1993) estimated the average intake of flavonols and flavones to be $23 \mathrm{mg} / \mathrm{d}$ in the Netherlands and around $64 \mathrm{mg} / \mathrm{d}$ in Japan. In western Europe, the flavonols quercetin, myricetin and kaempferol are consumed predominantly in the form of water-soluble glycosides in apples and onions, or as solutes in black tea and wine.

A variety of phenolic substances can inhibit promotion of carcinogenesis in the two-stage mouse skin model. For example, Gali et al. (1991) showed that topical application of a complex mixture of high molecular weight phenolic substances described as tannic acid inhibited the induction of ornithine decarboxylase activity by phorbol ester (12- $O$-tetradecanoylphorbol-13acetate). Quercetin and other flavonoids inhibit proliferation of human gastric cancer cells (Yoshida et al. 1992), and colonic carcinoma cells (Kuntz et al. 1999; Wenzel et al. 2000) by blocking the G1/S transition of the cell cycle and inducing apoptosis. It is increasingly recognized that intestinal epithelial cells may be exposed to higher concentrations of biologically active flavonoids than any other tissue in the body (Halliwell et al. 2000).

Part of the growth inhibitory effect of quercetin against the human tumour cell line HT29 appears to be due to induction of cell death, that is selective for cells expressing a less differentiated more tumour-like phenotype (Musk et al. 1995). Deschner et al. (1991) investigated the effects of quercetin, and the glycoside rutin, on the induction by azoxymethanol of crypt hyperproliferation and dysplasia in mouse colon. Mice received a semi-synthetic diet free of flavonoids, or the same diet containing 1,5 or $20 \mathrm{~g}$ quercetin/ $\mathrm{kg}$ or at 10 or $40 \mathrm{~g}$ rutin $/ \mathrm{kg}$ by weight. The treated groups received azoxymethanol and the control groups received a sham injection of saline $(9 \mathrm{~g} \mathrm{NaCl} / \mathrm{l})$. There was no observed effect of quercetin or rutin on the rate or spatial distribution of crypt cell proliferation in the control mice; but in those given azoxymethanol, consumption of $20 \mathrm{~g}$ quercetin/ $\mathrm{kg}$ or $40 \mathrm{~g}$ rutin/ $\mathrm{kg}$ was associated with the suppression of crypt cell hyperproliferation induced by the carcinogen, and a spatial re-localization of mitosis toward the lower part of the crypt. Matsukawa et al. (1997) explored the ability of quercetin $(20 \mathrm{~g} / \mathrm{kg}$ diet $)$ to reduce induction of ACF in rats treated with azoxymethanol and subjected to mild restraint stress and noted that induction of ACF was reduced in both the stressed and unstressed rats given quercetin compared with their respective controls. These results are consistent with recent studies in mice, reported by Yang et al. (2000).

Recent studies by Hara et al. (1999) seem to confirm that the principal effect of quercetin in the rat in vivo is the suppression of crypt cell mitosis, rather than any stimulus of cell deletion. Groups of animals were fed semi-synthetic powdered diets containing quercetin aglycone at concentrations of $1,5,20$ and $50 \mathrm{~g} / \mathrm{kg}$ diet. After a feeding period of $7 \mathrm{~d}$ the animals were killed, and full thickness samples of the intestinal tissue from the proximal, mid- and distal small intestine, and from the caecum, mid- and distal colon were excised and fixed for microscopy. In both the small bowel and distal colon of rats fed quercetin at the lowest dose there was a clear suppression of crypt cell proliferation compared with animals fed the quercetin-free diet. However this effect was markedly reduced as the level of quercetin in the diet increased. The reason for the disappearance of the anti-mitotic effect as the level of quercetin consumption increased is not immediately obvious. Possibly metabolites of quercetin derived from the gut, or from the liver, exert a pro-mitotic effect on the mucosal epithelium that is antagonistic to the anti-mitotic effect of the parent compound. In a second experiment, dietary supplementation with quercetin at the lowest concentration used previously suppressed mitosis during the recovery phase after treatment with DMH and reduced the number of ACF. This observation is consistent with the hypothesis that reducing the rate of cell proliferation during the critical phase of exposure to a methylating carcinogen can significantly suppress the level of DNA damage obtained.

Many human foods and beverages are rich in biologically active polyphenol compounds, 
including flavonoids, with well-established anti-mitotic and pro-apoptotic activity (Formica \& Regelson, 1995). Absorption of these compounds from the gut lumen is relatively slow. They are likely therefore to become concentrated in the gut lumen to relatively high levels, but they are also susceptible to degradation by colonic bacteria. It is by no means clear whether the effects of flavonoids and other biologically active phytochemicals on intestinal cells are due to the native compounds, or to their metabolites in the circulation. These factors make it difficult to judge the overall significance of flavonoids in relation to colorectal carcinogenesis. However, the tissues of the upper gastrointestinal tract, including the oesophagus and the gastric mucosa, can be exposed to very high concentrations of the native compounds present in tea and other beverages. Studies on the actions of anti-mitotic and pro-apoptotic flavonoids against pre-neoplastic lesions of the upper gastrointestinal tract, such as Barrett's oesophagus, might prove particularly valuable.

\section{Glucosinolate breakdown products}

The glucosinolates are a large group of organic S compounds found in plants of the order Capparales, which includes both wild and domestic brassica species, including cabbages, broccoli and Brussels sprouts. More than 100 different glucosinolates have been identified, the common structure of which comprises a $\beta$-D-thioglucose group and a sulfonated oxime moiety, bearing a variable side-chain derived from methionine, tryptophan, phenylalanine or various branched-chain amino acids (Mithen et al. 2000). The glucosinolates themselves are stable and largely inactive within the intact plant, but tissue damage causes them to come into contact with the endogenous enzyme thioglucoside glycohydrolase, commonly known as myrosinase. The glucosinolate undergoes rapid hydrolysis, releasing an unstable aglycone which then breaks down to form any of a variety of products, including nitriles and isothiocyanates. The latter are also called 'mustard oils' and they provide hot and bitter flavours to mustard, radishes, and brassica vegetables (Fenwick et al. 1983).

Isothiocyanates are amongst the most intensively studied dietary anticarcinogens, principally because of their proven ability to block the action of mutagens in model systems by modulating the activities of Phase I and Phase II biotransformation enzymes, including glutathione-S-transferase and UDP-glucuronyl transferase (Nijhoff et al. 1995; Hecht et al. 1996; Hecht, 1999). There is good evidence that consumption of brassica vegetables rich in their precursor glucosinolates is protective against cancer in humans, and particularly against those of the lung (van Poppel et al. 1999) and alimentary tract (Brown et al. 1995; Voorrips et al. 2000). Whilst lung cancer is caused primarily by exposure to tobacco smoke mutagens, the detoxification of which is increased by dietary exposure to glucosinolate breakdown products (Hecht et al. 1995), the role of environmental mutagens in colorectal carcinogenesis is less well established. Brassica vegetable consumption has been reported both to reduce the risk of adenomatous polyps (Lin et al. 1998), and to reduce the growth of established polyps (Hoff et al. 1988). It is therefore particularly appropriate to consider the effects of isothiocyanates on colorectal crypt cell proliferation and apoptosis.

It has been recognized for a number of years that isothiocyanates exert antimicrobial activity (Zsolnai, 1971). More recently Hasegawa et al. (1993) reported that benzyl and phenethyl isothiocyanates inhibited the growth of HeLa cells by inducing blockade of the cell cycle at $\mathrm{G} 2 / \mathrm{M}$, and there have also been reports of a selective toxic effect of allyl isothiocyanate (Musk \& Johnson, 1993), phenethyl isothiocyanate and benzyl isothiocyanate (Musk et al. 1995) against undifferentiated HT29 cells. It has been reported that exposure of human ovarian HeLa 
cells to phenethyl isothiocyanate led to increased levels of c-Jun N-terminal kinase 1 (Yu et al. 1996), and to apoptosis, associated with induction of caspase- 3 and cleavage of poly(ADPribose) polymerase (Yu et al. 1998). Human leukaemia cells (HL60) and human myeloblastic leukaemia 1 cells have also been reported to undergo caspase-dependent apoptosis following exposure to phenethyl isothiocyanate (Xu \& Thornalley, 2000).

The signalling pathways leading to induction of apoptosis by isothiocyanates remain to be established. An interesting parallel with the effects of butyrate on colorectal tumour cells is suggested by a recent study showing that treatment of murine erythroleukemia cells with allyl isothiocyanate led to increased histone acetylation, albeit via a mechanism that did not involve inhibition of histone deacetylase (Lea et al. 2001). The response of HT29 cells to allyl isothiocyanate in vitro is somewhat complex, in that although they become blocked in G2/M, and undergo nuclear condensation and detachment from the substratum, this process is not caspasedependent, and the floating cells do not exhibit classical markers of apoptosis (Lund et al. 2000). The failure to undergo the complete apoptotic programme may reflect the absence of wild-type $p 53$ expression in these cells (EK Lund and IT Johnson, unpublished results).

In an animal model of colorectal neoplasia, a semi-synthetic diet enriched with sinigrin, the glucosinolate precursor of allyl isothiocyanate, suppressed mitosis and induced an increased level of apoptosis in the colorectal crypts of rats $48 \mathrm{~h}$ after treatment with the colon carcinogen $\mathrm{DMH}$, but there was no significant effect of the compound on the colon of control rats (Smith et al. 1998). A juice derived by mechanical disruption of uncooked Brussels sprout tissue exerted much the same effects as allyl isothiocyanate on HT29 cells in vitro, and the same liquid, given to rats by tube-feeding, markedly increased basal crypt cell apoptosis after treatment with DMH (Smith et al. 2000b). Again there was no effect of the treatment on the intestinal mucosa of rats not previously exposed to DMH. Like the flavonoids, glucosinolates and their breakdown products undergo complex changes both before and after their passage through the digestive tract, and it is not yet clear whether the intestinal epithelial cells are exposed to isothiocyanates from the gut lumen, or whether blood-borne metabolites are of primary importance. Nevertheless the effects of these compounds in vitro, and in animal models, are remarkably consistent with the growing epidemiological evidence for protective effects of brassica vegetables against cancers of the alimentary tract. Further studies are needed to explore their routes of delivery and mechanisms of action in man.

\section{Conclusion}

The permanently high rates of cellular replication in the gastrointestinal epithelia, coupled with their life-long exposure to a complex external environment, make them particularly vulnerable to neoplasia. However, the wide geographical variations in incidence of cancers of the alimentary tract suggest that the process is not inevitable, and that the gut is potentially susceptible to protective mechanisms linked to diet. Some of these protective factors seem likely to act via effects on crypt cell cytokinetics. The unique accessibility of the gut to clinical endoscopy and the recent rapid advances in tumour biology provide exciting opportunities for the development of strategies for cancer chemoprevention. In this context the rapidly growing evidence for significant protective effects of NSAID against colorectal cancer offers considerable encouragement. Recently emerging evidence suggests that a number of natural dietary constituents may also exert significant and potentially beneficial effects on epithelial cell proliferation and apoptosis in the gut. There are many unresolved issues concerning the precise anatomical location of the cells that undergo somatic mutation and go on to form neoplastic lesions, the 
overall regulation of cell production and exfoliation in the gut, and the functional interrelationships between crypt epithelial mitosis, DNA repair and crypt cell apoptosis. It also remains to be determined whether diet can be used to manipulate these effects for preventive or therapeutic effect, and if so, at what stage of the individual's lifespan they are likely to be most effective.

\section{Acknowledgements}

The author is grateful to both the BBSRC and the European Union for financial support. Thanks are also due to Dr E K Lund for much helpful discussion and advice.

\section{References}

Adams JM \& Cory S (1998) The Bcl-2 protein family: arbiters of cell survival. Science 281, 1322-1326.

Adamson RH, Thorgeirsson UP \& Sugimura T (1996) Extrapolation of heterocyclic amine carcinogenesis data from rodents and nonhuman primates to humans. Archives of Toxicology 71, Suppl. 18, 303-318.

Afford S \& Randhawa S (2000) Apoptosis. Journal of Clinical Pathology: Molecular Pathology 53, 55-63.

Ames B \& Swirsky Gold L (1991) Mitogenesis, mutagenesis, and animal cancer tests. Chemically induced cell proliferation: implications for risk assessment. Progress in Clinical and Biological Research 369, 1-20.

Anti M, Armelao F, Marra G, Percesepe A, Bartoli GM, Palozza P, Parrella P, Canetta C, Gentiloni N, De Vitis I \& Gasbarrini G (1994) Effects of different doses of fish oil on rectal cell proliferation in patients with sporadic colonic adenomas. Gastroenterology 107, 1709-1718.

Antunes F \& Cadenas E (2001) Cellular titration of apoptosis with steady-state concentrations of $\mathrm{H}_{2} \mathrm{O}_{2}$ : submicromolar levels of $\mathrm{H}_{2} \mathrm{O}_{2}$ induce apoptosis through Fenton chemistry independent of the cellular thiol state. Free Radicals in Biology and Medicine 30, 1008-1018.

Augeron C \& Laboisse C (1984) Emergence of permanently differentiated cell clones in a human colonic cancer cell line in culture after treatment with sodium butyrate. Cancer Research 44, 3961-3969.

Avivi-Green C, Madar Z \& Schwartz B (2000a) Pectin-enriched diet affects distribution and expression of apoptosiscascade proteins in colonic crypts of dimethylhydrazine-treated rats. International Journal of Molecular Medicine 6, 689-698.

Avivi-Green C, Polak-Charcon S, Madar Z \& Schwartz B (2000b) Apoptosis cascade proteins are regulated in vivo by high intracolonic butyrate concentration: correlation with colon cancer inhibition. Oncology Research 12, 83-95.

Bach SP, Renehan AG \& Potten CS (2000) Stem cells: the intestinal stem cell as a paradigm. Carcinogenesis 21, 469-476.

Barnard JA \& Warwick G (1993) Butyrate rapidly induces growth inhibition and differentiation in HT-29 cells. Cell Growth and Differentiation 4, 495-501.

Barthold SW \& Beck D (1980) Modification of early dimethylhydrazine carcinogenesis by colonic mucosal hyperplasia. Cancer Research 40, 4451-4455.

Begin ME, Das UN, Ells G \& Horrobin DF (1985) Selective killing of human cancer cells by polyunsaturated fatty acids. Prostaglandins and Leukotrienes in Medicine 19, 177-186.

Begin ME, Ells G, Das UN \& Horrobin DF (1986) Differential killing of human carcinoma cells supplemented with n3 and n-6 polyunsaturated fatty acids. Journal of the National Cancer Institute 77, 1053-1062.

Bellamy CO, Malcomson RD, Harrison DJ \& Wyllie AH (1995) Cell death in health and disease: the biology and regulation of apoptosis. Seminars in Cancer Biology 6, 3-16.

Bielas JH \& Heddle JA (2000) Proliferation is necessary for both repair and mutation in transgenic mouse cells. Proceedings of the National Academy of Sciences USA 97, 11391-11396.

Bingham SA, Pignatelli B, Pollock JRA, Ellul A, Malaveille C, Gross G, Runswick S, Cummings JH \& O'Neill IK (1996) Does increased endogenous formation of N-nitroso compounds in the human colon explain the association between red meat and colon cancer? Carcinogenesis 17, 515-523.

Bodmer WF (1994) Cancer genetics. British Medical Bulletin 50, 517-526.

Bodmer WF (1999) 1998 Runme Shaw Memorial Lecture: Somatic evolution of cancer. Annals of the Academy of Medicine of Singapore 28, 323-329.

Boffa LC, Lupton JR, Mariani MR, Ceppi M, Newmark HL, Scalmati A \& Lipkin M (1992) Modulation of colonic epithelial cell proliferation, histone acetylation, and luminal short chain fatty acids by variation of dietary fiber (wheat bran) in rats. Cancer Research 52, 5906-5912.

Bonithon-Kopp C, Kronborg O, Giacosa A, Rath U \& Faivre J (2000) Calcium and fibre supplementation in prevention of colorectal adenoma recurrence: a randomised intervention trial. European Cancer Prevention Organisation Study Group. Lancet 356, 1300-1306. 
Bracey TS, Miller JC, Preece A \& Paraskeva C (1995) Gamma-radiation-induced apoptosis in human colorectal adenoma and carcinoma cell lines can occur in the absence of wild type p53. Oncogene 10, 2391-2396.

Brown LM, Swanson CA, Gridley G, Swanson GM, Schoenberg JB, Greenberg RS, Silverman DT, Pottern LM, Hayes RB, Schwartz AG, Liff JM, Fraumeni JF \& Hoover RN (1995) Adenocarcinoma of the esophagus: role of obesity and diet. Journal of the National Cancer Institute 87, 104-109.

Caderni G, Luceri C, De Filippo C, Salvadori M, Giannini A, Tessitore L \& Dolara P (2001) Slow-release pellets of sodium butyrate do not modify azoxymethane (AOM)-induced intestinal carcinogenesis in F344 rats. Carcinogenesis 22, 525-527.

Caderni G, Luceri C, Lancioni L, Tessitore L \& Dolara P (1998) Slow-release pellets of sodium butyrate increase apoptosis in the colon of rats treated with azoxymethane, without affecting aberrant crypt foci and colonic proliferation. Nutrition and Cancer 30, 175-181.

Cai WB, Roberts SA \& Potten CS (1997) The number of clonogenic cells in crypts in three regions of murine large intestine. International Journal of Radiation Biology 71, 573-579.

Chai F, Evdokiou A, Young GP \& Zalewski PD (2000) Involvement of p21(Waf1/Cip1) and its cleavage by DEVDcaspase during apoptosis of colorectal cancer cells induced by butyrate. Carcinogenesis 21, 7-14.

Chan TA, Morin PJ, Vogelstein B \& Kinzler KW (1998) Mechanisms underlying nonsteroidal antiinflammatory drugmediated apoptosis. Proceedings of the National Academy of Sciences USA 95, 681-686.

Chang W, Chapkin RS \& Lupton JR (1997) Predictive value of proliferation, differentiation and apoptosis as intermediate markers for colon tumorigenesis. Carcinogenesis 18, 721-730.

Chapkin RS, Fan Y \& Lupton JR (2000) Effect of diet on colonic-programmed cell death: molecular mechanism of action. Toxicology Letters 112-113, 411-414.

Clarke RG, Lund EK, Latham P, Pinder AC \& Johnson IT (1999) Effect of eicosapentaenoic acid on the proliferation and incidence of apoptosis in the colorectal cell line HT29. Lipids 34, 1287-1295.

Cohen GM (1997) Caspases: the executioners of apoptosis. Biochemical Journal 326, 1-16.

Cosentino L, Shaver-Walker P \& Heddle JA (1996) The relationships among stem cells, crypts, and villi in the small intestine of mice as determined by mutation tagging. Developmental Dynamics 207, 420-428.

Cummings JH, Pomare EW, Branch WJ, Naylor CPE \& Macfarlane GT (1987) Short chain fatty acids in human large intestine, portal, hepatic and venous blood. Gut 28, 1221-1227.

Das UN (1991) Tumoricidal action of cis-unsaturated fatty acids and their relationship to free radicals and lipid peroxidation. Cancer Letters 56, 235-243.

De Filippo C, Caderni G, Bazzicalupo M, Briani C, Giannini A, Fazi M \& Dolara P (1998) Mutations of the Apc gene in experimental colorectal carcinogenesis induced by azoxymethane in F344 rats. British Journal of Cancer $\mathbf{7 7}$ 2148-2151.

Della Ragione F, Criniti V, Della Pietra V, Borriello A, Oliva A, Indaco S, Yamamoto T \& Zappia V (2001) Genes modulated by histone acetylation as new affectors of butyrate activity. FEBS Letters 499, 199-204.

Deschner EE, Ruperto J, Wong G \& Newmark HL (1991) Quercetin and rutin as inhibitors of azoxymethanol-induced colonic neoplasia. Carcinogenesis 12, 1193-1196.

Deveraux QL, Stennicke HR, Salvesen GS \& Reed JC (1999) Endogenous inhibitors of caspases. Journal of Clinical Immunology 19, 388-398.

de Wind N, Dekker M, Berns A, Radman M \& te Riele H (1995) Inactivation of the mouse Msh2 gene results in mismatch repair deficiency, methylation tolerance, hyperrecombination, and predisposition to cancer. Cell 82, 321-330.

Earnshaw WC, Martins LM \& Kaufmann SH (1999) Mammalian caspases: structure, activation, substrates and functions during apoptosis. Annual Reviews of Biochemistry 68, 383-424.

Eberhart CE, Coffey RJ, Radhika A, Giardiello FM, Ferrenbach S \& DuBois RN (1994) Up-regulation of cyclooxygenase 2 gene expression in human colorectal adenomas and adenocarcinomas. Gastroenterology 107, 1183-1188.

Elder DJ, Halton DE, Crew TE \& Paraskeva C (2000) Apoptosis induction and cyclooxygenase-2 regulation in human colorectal adenoma and carcinoma cell lines by the cyclooxygenase-2-selective non-steroidal anti-inflammatory drug NS-398. International Journal of Cancer 86, 553-560.

Ellis HM \& Horvitz HR (1986) Genetic control of programmed cell death in the nematode C. elegans. Cell 44, 817-829.

Fadeel B, Orrenius S \& Zhivotovsky B (2000) The most unkindest cut of all: on the multiple roles of mammalian caspases. Leukemia 14, 1514-1525.

Farber E (1995) Cell proliferation as a major risk factor for cancer: a concept of doubtful validity. Cancer Research $\mathbf{5 5}$ 3759-3762.

Fay MP, Freedman LS, Clifford CK \& Midthune DN (1997) Effect of different types and amounts of fat on the development of mammary tumors in rodents: a review. Cancer Research 57, 3979-3988.

Fearon ER, Hamilton SR \& Vogelstein B (1987) Clonal analysis of human colorectal tumors. Science 238, $193-197$.

Fenwick GR, Heaney RK \& Mullin WJ (1983) Glucosinolates and their breakdown products in food and food plants. Critical Reviews in Food Science and Nutrition 18, 123-201.

Finstad HS, Myhrstad MC, Heimli H, Lomo J, Blomhoff HK, Kolset SO \& Drevon CA (1998) Multiplication and death-type of leukemia cell lines exposed to very long-chain polyunsaturated fatty acids. Leukemia 12, 921-929.

Flemming W (1885) Uber die Bildung von Richtungsfiguren in Saugerthiereiern beim Untergang Graaf scher Follikel 
(On interpreting the regression of ammalian lymphoid follicles). Archiv für Anatomie und Entwicklungsgeschichte 1885, 221-224.

Formica JV \& Regelson W (1995) Review of the biology of quercetin and related bioflavonoids. Food and Chemical Toxicology 33, 1061-1080.

Frisch SM \& Francis H (1994) Disruption of epithelial cell-matrix interactions induces apoptosis. Journal of Cell Biology 124, 619-626.

Fussenegger M, Bailey JE \& Varner J (2000) A mathematical model of caspase function in apoptosis. Nature Biotechnology 18, 768-774.

Gafa R \& Lanza G (1998) Expression of protein p53 in the adenoma-colorectal carcinoma sequence. Pathologica 90, 351-356.

Gali HU, Perchellet EM \& Perchellet JP (1991) Inhibition of tumor promoter-induced ornithine decarboxylase activity by tannic acid and other polyphenols in mouse epidermis in vivo. Cancer Research 51, 2820-2825.

Gann PH, Manson JE, Glynn RJ, Buring JE \& Hennekens CH (1993) Low-dose aspirin and incidence of colorectal tumors in a randomized trial. Journal of the National Cancer Institute 85, 1220-1224.

Glucksmann A (1951) Cell deaths in normal vertebrate ontogeny. Biological Reviews of the Cambridge Philosophical Society 26, 59-86.

Goodlad RA, Lenton W, Ghatei MA, Adrian TE, Bloom SR \& Wright NA (1987) Proliferative effects of 'fibre' on the intestinal epithelium: relationship to gastrin, enteroglucagon and PYY. Gut 28, 221-226.

Goodlad RA, Levi S, Lee CY, Mandir N, Hodgson H \& Wright NA (1991) Morphometry and cell proliferation in endoscopic biopsies: evaluation of a technique. Gastroenterology 101, 1235-1241.

Graper L (1914) Eine neue Anschauung uber physiologische Zellausschaltung (A new outlook on physiological cell deletion). Archiv für Zellforschung 13, 373-374.

Groden J, Nakamura Y \& German J (1990) Molecular evidence that homologous recombination occurs in proliferating human somatic cells. Proceedings of the National Academy of Sciences USA 87, 4315-4319.

Grossmann J, Artinger M, Grasso AW, Kung HJ, Scholmerich J, Fiocchi C \& Levine AD (2001) Hierarchical cleavage of focal adhesion kinase by caspases alters signal transduction during apoptosis of intestinal epithelial cells. Gastroenterology 120, 79-88.

Hagopian HK, Riggs MG, Swartz LA \& Ingram VM (1977) Effect of n-butyrate on DNA synthesis in chick fibroblasts and HeLa cells. Cell 12, 855-860.

Hague A, Elder DJ, Hicks DJ \& Paraskeva C (1995) Apoptosis in colorectal tumour cells: induction by the short chain fatty acids butyrate, propionate and acetate and by the bile salt deoxycholate. International Journal of Cancer 60, 400-406.

Hague A, Manning AM, Hanlon KA, Huschtscha LI, Hart D \& Paraskeva C (1993) Sodium butyrate induces apoptosis in human colonic tumour cell lines in a p53-independent pathway: implications for the possible role of dietary fibre in the prevention of large-bowel cancer. International Journal of Cancer 55, 498-505.

Halliwell B, Zhao K \& Whiteman M (2000) The gastrointestinal tract: a major site of antioxidant action? Free Radical Research 33, 819-830.

Hara H, Gee JM \& Johnson IT (1999) Antiproliferative effects of quercetin in the rat gastrointestinal tract. In Proceedings of the Seventh Scientific Workshop of COST 98, vol. EUR 19229 EN, pp. 49-53 [A Krogdahl, SD Mathieson and IF Pryme, editors]. Brussels: European Commission.

Hardman WE, Cameron IL, Heitman DW \& Contreras E (1991) Demonstration of the need for end point validation of putative biomarkers: failure of aberrant crypt foci to predict colon cancer incidence. Cancer Research 51, 6388-6392.

Harig JM, Soergel KH, Komorowski RA \& Wood CM (1989) Treatment of diversion colitis with short chain fatty acid irrigation. New England Journal of Medicine 320, 23-28.

Hasegawa T, Nishino H \& Iwashima A (1993) Isothiocyanates inhibit cell cycle progression of HeLa cells at G2/M phase. Anticancer Drugs 4, 273-279.

Hass R, Busche R, Luciano L, Reale E \& Engelhardt WV (1997) Lack of butyrate is associated with induction of Bax and subsequent apoptosis in the proximal colon of guinea pig. Gastroenterology 112, 875-881.

Hawkins RA, Sangster K \& Arends MJ (1998) Apoptotic death of pancreatic cancer cells induced by polyunsaturated fatty acids varies with double bond number and involves an oxidative mechanism. Journal of Pathology 185, 61-70.

Hecht SS (1999) Chemoprevention of cancer by isothiocyanates, modifiers of carcinogen metabolism. Journal of Nutrition 129, 768S-774S.

Hecht SS, Chung FL, Richie JP Jr, Akerkar SA, Borukhova A, Skowronski L \& Carmella SG (1995) Effects of watercress consumption on metabolism of a tobacco-specific lung carcinogen in smokers. Cancer Epidemiology Biomarkers and Prevention 4, 877-884.

Hecht SS, Trushin N, Rigotty J, Carmella SG, Borukhova A, Akerkar S, Desai D, Amin S \& Rivenson A (1996) Inhibitory effects of 6-phenylhexyl isothiocyanate on 4-(methylnitrosamino)-1-(3-pyridyl)-1-butanone metabolic activation and lung tumorigenesis in rats. Carcinogenesis 17, 2061-2067.

Heddle JA, Cosentino L, Dawod G, Swiger RR, Paashuis-Lew Y (1996) Why do stem cells exist? Environmental and Molecular Mutagenesis 28, 334-341.

Heerdt BG, Houston MA \& Augenlicht LH (1994) Potentiation by specific short-chain fatty acids of differentiation and apoptosis in human colonic carcinoma cell lines. Cancer Research 54, 3288-3293.

Hertog MG, Hollman PC, Katan MB \& Kromhout D (1993) Intake of potentially anticarcinogenic flavonoids and their determinants in adults in The Netherlands. Nutrition and Cancer 20, 21-29. 
Hill MJ, Morson BC, Bussey HJ (1978) Aetiology of adenoma-carcinoma sequence in large bowel. Lancet i, $245-247$.

Hoff G, Moen IE, Trygg K, Frolich W, Foerster A, Vatn M, Sauar J \& Larsen S (1988) Colorectal adenomas and food. A prospective study of change in volume and total mass of adenomas in man. Scandinavian Journal of Gastroenterology 23, 1253-1258.

Hursting SD, Thornquist M \& Henderson MM (1990) Types of dietary fat and the incidence of cancer at five sites. Preventative Medicine 19, 242-253.

Jacobs LR \& Lupton JR (1986) Relationship between colonic luminal pH, cell proliferation, and colon carcinogenesis in 1,2-dimethylhydrazine treated rats fed high fiber diets. Cancer Research 46, 1727-1734.

James JT \& Autrup H (1983) Methylated DNA adducts in the large intestine of ICR/Ha and C57BL/Ha mice given 1,2dimethylhydrazine. Journal of the National Cancer Institute 70, 541-546.

Kargman SL, O’Neill GP, Vickers PJ, Evans JF, Mancini JA \& Jothy S (1995) Expression of prostaglandin G/H synthase-1 and -2 protein in human colon cancer. Cancer Research 55, 2556-2559.

Kashtan H, Stern HS, Jenkins DJ, Jenkins AL, Thompson LU, Hay K, Marcon N, Minkin S \& Bruce WR (1992) Colonic fermentation and markers of colorectal-cancer risk. American Journal of Clinical Nutrition 55, 723-728.

Kerr JF (1971) Shrinkage necrosis: a distinct mode of cellular death. Journal of Pathology 105, 13-20.

Kerr JF, Wyllie AH \& Currie AR (1972) Apoptosis: a basic biological phenomenon with wide-ranging implications in tissue kinetics. British Journal of Cancer 26, 239-257.

Kinzler KW \& Vogelstein B (1996) Lessons from hereditary colorectal cancer. Cell 87, 159-170.

Kluck RM, Bossy-Wetzel E, Green DR \& Newmeyer DD (1997) The release of cytochrome c from mitochondria: a primary site for Bcl-2 regulation of apoptosis. Science 275, 1132-1136.

Kozoni V, Tsioulias G, Shiff S \& Rigas B (2000) The effect of lithocholic acid on proliferation and apoptosis during the early stages of colon carcinogenesis: differential effect on apoptosis in the presence of a colon carcinogen. Carcinogenesis 21, 999-1005.

Kripke SA, Fox AD \& Berman JR (1989) Stimulation of intestinal mucosal growth with intracolonic infusion of short chain fatty acids. Journal of Parenteral and Enteral Nutrition 13, 109-116.

Kuida K, Lippke JA, Ku G, Harding MW, Livingston DJ, Su MS \& Flavell RA (1995) Altered cytokine export and apoptosis in mice deficient in interleukin-1 beta converting enzyme. Science 267, 2000-2003.

Kuntz S, Wenzel U \& Daniel H (1999) Comparative analysis of the effects of flavonoids on proliferation, cytotoxicity, and apoptosis in human colon cancer cell lines. European Journal of Nutrition 38, 133-142.

Kuwana T, Smith JJ, Muzio M, Dixit V, Newmeyer DD \& Kornbluth S (1998) Apoptosis induction by caspase-8 is amplified through the mitochondrial release of cytochrome c. Journal of Biological Chemistry 273, 16589-16594.

Lamlum H, Papadopoulou A, Ilyas M, Rowan A, Gillet C, Hanby A, Talbot I, Bodmer W \& Tomlinson I (2000) APC mutations are sufficient for the growth of early colorectal adenomas. Proceedings of the National Academy of Sciences USA 97, 2225-2228.

Lancaster T \& Silagy C (1994) Aspirin and neoplasia of the digestive tract: is there a chemopreventive effect? Digestive Diseases 12, 170-176.

Latham P, Lund EK, Brown JC \& Johnson IT (2001) Effects of cellular redox balance on induction of apoptosis by eicosapentaenoic acid in HT29 colorectal adenocarcinoma cells and rat colon in vivo. Gut 49, 97-105.

Latham P, Lund EK \& Johnson IT (1998) Modulation of colonocyte proliferation and apoptosis by dietary fish oil in experimental colorectal carcinogenesis. Biochemical Society Transactions 26, S158.

Latham P, Lund EK \& Johnson IT (1999) Dietary n-3 PUFA increases the apoptotic response to 1,2-dimethylhydrazine, reduces mitosis and suppresses the induction of carcinogenesis in the rat colon. Carcinogenesis 20, 645-650.

Lea MA, Randolph VM, Lee JE \& desBourdes C (2001) Induction of histone acetylation in mouse erythroleukemia cells by organosulfur compounds including acetyl isothiocyanate. International Journal of Cancer 92, 784-789.

Lee FD (1993) Importance of apoptosis in the histopathology of drug related lesions in the large intestine. Journal of Clinical Pathology 46, 118-122.

Lennard-Jones J (2001) Annual Review. London: Digestive Disorders Foundation.

Li M, Ona VO, Chen M, Kaul M, Tenneti L, Zhang X, Stieg PE, Lipton SA \& Friedlander RM (2000) Functional role and therapeutic implications of neuronal caspase-1 and -3 in a mouse model of traumatic spinal cord injury. Neuroscience 99, 333-342.

Lin HJ, Probst-Hensch NM, Louie AD, Kau IH, Witte JS, Ingles SA, Frankl HD, Lee ER \& Haile RW (1998) Glutathione transferase null genotype, broccoli, and lower prevalence of colorectal adenomas. Cancer Epidemiology Biomarkers and Prevention 7, 647-652.

Loeb LA (1994) Microsatellite instability: marker of a mutator phenotype in cancer. Cancer Research 54, 5059-5063.

Loeb LA (1998) Cancer cells exhibit a mutator phenotype. Advances in Cancer Research 72, 25-56.

Loeffler M, Birke A, Winton D \& Potten C (1993) Somatic mutation, monoclonality and stochastic models of stem cell organization in the intestinal crypt. Journal of Theoretical Biology 160, 471-491.

Lund EK \& Johnson IT (1991) Fermentable carbohydrate reaching the colon after ingestion of oats in humans. Journal of Nutrition 121, 311-317.

Lund EK, Smith TK, Latham P, Clarke R \& Johnson IT (2000) Influence of biologically active food constituents on apoptosis and cell cycle in colorectal epithelial cells. In Dietary Anticarcinogens and Antimutagens: Chemical and Biological Aspects, pp. 333-337 [IT Johnson and GR Genwick, editors]. Cambridge: Royal Society of Chemistry.

Lutz WK \& Schlatter J (1992) Chemical carcinogens and overnutrition in diet-related cancer. Carcinogenesis 13, 2211-2216. 
Lynch HT \& Krush AJ (1971) Cancer family 'G' revisited: 1895-1970. Cancer 27, 1505-1511.

Majno G \& Joris I (1999) Commentary: On the misuse of the term 'necrosis': a step in the right direction. Toxicologic Pathology 27, 494.

Mandal M, Olson DJ, Sharma T, Vadlamudi RK \& Kumar R (2001) Butyric acid induces apoptosis by up-regulating Bax expression via stimulation of the c-Jun N-terminal kinase/activation protein-1 pathway in human colon cancer cells. Gastroenterology 120, 71-78.

Markowitz AJ \& Winawer SJ (1999) Screening and surveillance for colorectal cancer. Seminars in Oncology 26, 485-498.

Marx J (2001) Cancer research. Anti-inflammatories inhibit cancer growth - but how? Science 291, 581-582.

Maskens AP \& Dujardin-Loits RM (1981) Experimental adenomas and carcinomas of the large intestine behave as distinct entities: most carcinomas arise de novo in flat mucosa. Cancer 47, 81-89.

Matsukawa Y, Nishino H, Okuyama Y, Matsui T, Matsumoto T, Matsumura S, Shimizu Y, Sowa Y \& Sakai T (1997) Effects of quercetin and/or restraint stress on formation of aberrant crypt foci induced by azoxymethane in rat colons. Oncology 54, 118-121.

Matthew JA, Pell JD, Prior A, Kennedy HJ, Fellows IW, Gee JM, Burton J \& Johnson IT (1994) Validation of a simple technique for the detection of abnormal mucosal cell replication in humans. European Journal of Cancer Prevention 3, 337-344.

Merritt AJ, Potten CS, Kemp CJ, Hickman JA, Balmain A, Lane DP \& Hall PA (1994) The role of p53 in spontaneous and radiation-induced apoptosis in the gastrointestinal tract of normal and p53-deficient mice. Cancer Research 54, 614-617.

Merritt AJ, Potten CS, Watson AJ, Loh DY, Nakayama K \& Hickman JA (1995) Differential expression of bcl-2 in intestinal epithelia. Correlation with attenuation of apoptosis in colonic crypts and the incidence of colonic neoplasia. Journal of Cell Science 108, 2261-2271.

Mithen RF, Dekker M, Verkerk R, Rabot S \& Johnson IT (2000) The nutritional significance, biosynthesis and bioavailability of glucosinolates in human foods. Journal of the Science of Food and Agriculture 80, 967-984.

Miura M, Zhu H, Rotello R, Hartwieg EA \& Yuan J (1993) Induction of apoptosis in fibroblasts by IL-1 beta-converting enzyme, a mammalian homolog of the $C$. elegans cell death gene ced-3. Cell 75, 653-660.

Mortensen FV, Hessov I, Birke H, Korsgaard N \& Nielsen H (1991) Microcirculatory and trophic effects of short chain fatty acids in the human rectum after Hartmann's procedure. British Journal of Surgery 78, 1208-1211.

Mortensen PB \& Clausen MR (1996) Short-chain fatty acids in the human colon: relation to gastrointestinal health and disease. Scandinavian Journal of Gastroenterology 31, Suppl. 216, 132-148.

Musk SR \& Johnson IT (1993) Allyl isothiocyanate is selectively toxic to transformed cells of the human colorectal tumour line HT29. Carcinogenesis 14, 2079-2083.

Musk SR, Stephenson P, Smith TK, Stening P, Fyfe D \& Johnson IT (1995) Selective toxicity of compounds naturally present in food toward the transformed phenotype of human colorectal cell line HT29. Nutrition and Cancer 24, 289-298.

Muzio M (1998) Signalling by proteolysis: death receptors induce apoptosis. International Journal of Clinical and Laboratory Research 28, 141-147.

Nijhoff WA, Grubben MJ, Nagengast FM, Jansen JB, Verhagen H, van Poppel G \& Peters WH (1995) Effects of consumption of Brussels sprouts on intestinal and lymphocytic glutathione S-transferases in humans. Carcinogenesis 16, 2125-2128.

Palmerini F, Devilard E, Jarry A, Birg F \& Xerri L (2001) Caspase 7 downregulation as an immunohistochemical marker of colonic carcinoma. Human Pathology 32, 461-467.

Palozza P, Calviello G, Serini S, Maggiano N, Lanza P, Raneletti FO \& Bartoli GM (2001) $\beta$-Carotene at high concentrations induces apoptosis by enhancing oxy-radical production in human adenocarcinoma cells. Free Radicals in Biology and Medicine 30, 1000-1007.

Partik G, Kahl-Rainer P, Sedivy R, Ellinger A, Bursch W \& Marian B (1998) Apoptosis in human colorectal tumours: ultrastructure and quantitative studies on tissue localization and association with bak expression. Virchows Archiv 432, 415-426.

Pasricha PJ, Bedi A, O’Connor K, Rashid A, Akhtar AJ, Zahurak ML, Piantadosi S, Hamilton SR \& Giardiello FM (1995) The effects of sulindac on colorectal proliferation and apoptosis in familial adenomatous polyposis. Gastroenterology 110, 1323-1324.

Pell JD, Brown JC \& Johnson IT (1994) Polyunsaturated fatty acids of the n-3 series influence intestinal crypt cell production in rats. Carcinogenesis 15, 1115-1119.

Pell JD, Johnson IT \& Goodlad RA (1995) The effects of and interactions between fermentable dietary fiber and lipid in germfree and conventional mice. Gastroenterology 108, 1745-1752.

Perrin P, Pierre F, Patry Y, Champ M, Berreur M, Pradal G, Bornet F, Meflah K \& Menanteau J (2001) Only fibres promoting a stable butyrate producing colonic ecosystem decrease the rate of aberrant crypt foci in rats. Gut $\mathbf{4 8}$, 53-61.

Piazza GA, Rahm AL, Krutzsch M, Sperl G, Paranka NS, Gross PH, Brendel K, Burt RW, Alberts DS, Pamukcu R \& Ahnen DJ (1995) Antineoplastic drugs sulindac sulfide and sulfone inhibit cell growth by inducing apoptosis. Cancer Research 55, 3110-3116.

Pollard M \& Luckert PH (1980) Indomethacin treatment of rats with dimethylhydrazine-induced intestinal tumors. Cancer Treatment Reports 64, 1323-1327. 
Polyak K, Xia Y, Zweier JL, Kinzler KW \& Vogelstein B (1997) A model for p53-induced apoptosis. Nature 389, 300-305.

Potten CS (1986) Cell cycles in cell hierarchies. International Journal of Radiation Biology and Related Studies in Physics, Chemistry, and Medicine 49, 257-278.

Potten CS (1992) The significance of spontaneous and induced apoptosis in the gastrointestinal tract of mice. Cancer Metastasis Reviews 11, 179-195.

Potten CS, Li YQ, O'Connor PJ \& Winton DJ (1992) A possible explanation for the differential cancer incidence in the intestine, based on distribution of the cytotoxic effects of carcinogens in the murine large bowel. Carcinogenesis $\mathbf{1 3}$ 2305-2312.

Potten CS \& Morris RJ (1988) Epithelial stem cells in vivo. Journal of Cell Science, Suppl. 10, 45-62.

Preston-Martin S, Pike MC, Ross RK, Jones PA \& Henderson BE (1990) Increased cell division as a cause of human cancer. Cancer Research 50, 7415-7421.

Pretlow TP, Barrow BJ, Ashton WS, O’Riordan MA, Pretlow TG, Jurcisek JA \& Stellato TA (1991) Aberrant crypts: putative preneoplastic foci in human colonic mucosa. Cancer Research 51, 1564-1567.

Pritchard DM, Potten CS \& Hickman JA (1998) The relationship between p53-dependent apoptosis, inhibition of proliferation, and 5-fluorouracil-induced histopathology in murine intestinal epithelia. Cancer Research 58, 5453-5465.

Pritchard DM, Print C, O'Reilly L, Adams JM, Potten CS \& Hickman JA (2000) Bcl-w is an important determinant of damage-induced apoptosis in epithelia of small and large intestine. Oncogene 19, 3955-3959.

Ramesh G \& Das UN (1998) Effect of cis-unsaturated fatty acids on Meth-A ascitic tumour cells in vitro and in vivo. Cancer Letters 123, 207-214.

Reddy BS (1992) Dietary fat and colon cancer: animal model studies. Lipids 27, 807-813.

Reinacher-Schick A, Seidensticker F, Petrasch S, Reiser M, Philippou S, Theegarten D, Freitag G \& Schmiegel W (2000) Mesalazine changes apoptosis and proliferation in normal mucosa of patients with sporadic polyps of the large bowel. Endoscopy 32, 245-254.

Roberts SA, Hendry JH \& Potten CS (1995) Deduction of the clonogen content of intestinal crypts: a direct comparison of two-dose and multiple-dose methodologies. Radiation Research 141, 303-308.

Roberts SA \& Potten CS (1994) Clonogen content of intestinal crypts: its deduction using a microcolony assay on whole mount preparations and its dependence on radiation dose. International Journal of Radiation Biology $\mathbf{6 5}$, 477-481.

Roediger WE (1990) The starved colon - diminished mucosal nutrition, diminished absorption, and colitis. Diseases of Colon and Rectum 33, 858-862.

Roncucci L, Pedroni M, Vaccina F, Benatti P, Marzona L \& De Pol A (2000) Aberrant crypt foci in colorectal carcinogenesis. Cell and crypt dynamics. Cell Proliferation 33, 1-18.

Rubio CA, Hubbard GB \& Frost P (2001) Apoptotic colonic disease: a new entity in a primate. In Vivo 15, 35-37.

Ruemmele F, Ruemmele C, Levy E \& Seidman E (1999) Les mecanismes moleculaires de la regulation du renouvellement des cellules epitheliales intestinales par des nutriments (Molecular mechanisms for the regulation of intestinal epithelial cell renewal by nutrients). Gastroenterologie Clinique et Biologique 23, 47-55.

Sakata T \& von Engelhardt W (1983) Stimulatory effect of short chain fatty acids on the epithelial cell proliferation in rat large intestine. Comparative Biochemistry and Physiology 74A, 459-462.

Sano H, Kawahito Y, Wilder RL, Hashiramoto A, Mukai S, Asai K, Kimura S, Kato H, Kondo M \& Hla T (1995) Expression of cyclooxygenase-1 and -2 in human colorectal cancer. Cancer Research 55, 3785-3789.

Schloss I, Kidd MS, Tichelaar HY, Young GO \& O'Keefe SJ (1997) Dietary factors associated with a low risk of colon cancer in coloured west coast fishermen. South African Medical Journal 87, 152-158.

Shiff SJ, Qiao L, Tsai LL \& Rigas B (1995) Sulindac sulfide, an aspirin-like compound, inhibits proliferation, causes cell cycle quiescence, and induces apoptosis in HT-29 colon adenocarcinoma cells. Journal of Clinical Investigation 96, 491-503.

Shih IM, Wang TL, Traverso G, Romans K, Hamilton SR, Ben-Sasson S, Kinzler KW \& Vogelstein B (2001) Topdown morphogenesis of colorectal tumors. Proceedings of the National Academy of Sciences USA 98, 2640-2645.

Shivapurkar N, Tang Z, Ferreira A, Nasim S, Garett C \& Alabaster O (1994) Sequential analysis of K-ras mutations in aberrant crypt foci and colonic tumors induced by azoxymethane in Fischer-344 rats on high-risk diet. Carcinogenesis 15, 775-778.

Siavoshian S, Segain JP, Kornprobst M, Bonnet C, Cherbut C, Galmiche JP \& Blottiere HM (2000) Butyrate and trichostatin A effects on the proliferation/differentiation of human intestinal epithelial cells: induction of cyclin D3 and p21 expression. Gut 46, 507-514.

Singh B, Halestrap AP \& Paraskeva C (1997) Butyrate can act as a stimulator of growth or inducer of apoptosis in human colonic epithelial cell lines depending on the presence of alternative energy sources. Carcinogenesis $\mathbf{1 8}$ 1265-1270.

Smith AJ, Stern HS, Penner M, Hay K, Mitri A, Bapat BV \& Gallinger S (1994) Somatic APC and K-ras codon 12 mutations in aberrant crypt foci from human colons. Cancer Research 54, 5527-5530.

Smith ML, Hawcroft G \& Hull MA (2000a) The effect of non-steroidal anti-inflammatory drugs on human colorectal cancer cells: evidence of different mechanisms of action. European Journal of Cancer 36, 664-674.

Smith TK, Clarke R, Scott J \& Johnson IT (2000b) Raw Brussels sprouts block mitosis in colorectal cancer cells (HT29) and induce apoptosis in rat colonic mucosal crypts in vivo. In Dietary Anticarcinogens and Antimutagens: Chemical and Biological Aspects [IT Johnson and GR Fenwick, editors]. Cambridge: Royal Society of Chemistry. 
Smith TK, Lund EK \& Johnson IT (1998) Inhibition of dimethylhydrazine-induced aberrent crypt foci and induction of apoptosis in rat colon following oral administration of the glucosinolate sinigrin. Carcinogenesis 19, 267-273.

Soussi T (2000) The p53 tumor suppressor gene: from molecular biology to clinical investigation. Annals of the New York Academy of Sciences 910, 121-137.

Steinbach G, Lynch PM, Phillips RK, Wallace MH, Hawk E, Gordon GB, Wakabayashi N, Saunders B, Shen Y, Fujimura T, Su LK \& Levin B (2000) The effect of celecoxib, a cyclooxygenase-2 inhibitor, in familial adenomatous polyposis. New England Journal of Medicine 342, 1946-1952.

Stoner GD, Budd GT, Ganapathi R, DeYoung B, Kresty LA, Nitert M, Fryer B, Church JM, Provencher K, Pamukcu R, Piazza G, Hawk E, Kelloff G, Elson P \& van Stolk RU (1999) Sulindac sulfone induced regression of rectal polyps in patients with familial adenomatous polyposis. Advances in Experimental Medicine and Biology 470, 45-53.

Strater J, Wellisch I, Riedl S, Walczak H, Koretz K, Tandara A, Krammer PH \& Moller P (1997) CD95(APO-1/Fas)mediated apoptosis in colon epithelial cells: a possible role in ulcerative colitis. Gastroenterology 113, 345-348.

Sulston JE \& Horvitz HR (1977) Post-embryonic cell lineages of the nematode, Caenorhabditis elegans. Developmental Biology 56, 110-156.

Takayama T, Katsuki S, Takahashi Y, Ohi M, Nojiri S, Sakamaki S, Kato J, Kogawa K, Miyake H \& Niitsu Y (1998) Aberrant crypt foci of the colon as precursors of adenoma and cancer. New England Journal of Medicine 339, 1277-1284.

Tannenbaum A \& Silverstone H (1953) Nutrition in relation to cancer. Advances in Cancer Research 1, 451-465.

Toft NJ, Winton DJ, Kelly J, Howard LA, Dekker M, te Riele H, Arends MJ, Wyllie AH, Margison GP \& Clarke AR (1999) Msh2 status modulates both apoptosis and mutation frequency in the murine small intestine. Proceedings of the National Academy of Sciences USA 96, 3911-3915.

Tomlinson I \& Bodmer W (1999) Selection, the mutation rate and cancer: ensuring that the tail does not wag the dog. Nature Medicine 5, 11-12.

Tomlinson IP \& Bodmer WF (1995) Failure of programmed cell death and differentiation as causes of tumors: some simple mathematical models. Proceedings of the National Academy of Sciences USA 92, 11130-11134.

Tomlinson IP, Novelli MR \& Bodmer WF (1996) The mutation rate and cancer. Proceedings of the National Academy of Sciences USA 93, 14800-14803.

Tong C, Fazio M \& Williams GM (1980) Cell-cycle specific mutagenesis at the hypoxanthine phosphoribosyltransferase locus in adult rat liver epithelial cells. Proceedings of the National Academy of Sciences USA 77, 7377-7379.

Tsujii M \& DuBois RN (1995) Alterations in cellular adhesion and apoptosis in epithelial cells overexpressing prostaglandin endoperoxide synthase 2 . Cell 83, 493-501.

Vane JR \& Botting RM (1998) Mechanism of action of antiinflammatory drugs. International Journal of Tissue Reactions 20, 3-15.

van Poppel G, Verhoeven DT, Verhagen H \& Goldbohm RA (1999) Brassica vegetables and cancer prevention. Epidemiology and mechanisms. Advances in Experimental Medicine and Biology 472, 159-168.

Virchow R \& Chandler AB (editors) (1859) Cellular Pathology as Based upon Physiological and Pathological Histology. New York: Dover Publications.

Vogelstein B, Fearon ER, Hamilton SR, Kern SE, Preisinger AC, Leppert M, Nakamura Y, White R, Smits AM \& Bos JL (1988) Genetic alterations during colorectal-tumor development. New England Journal of Medicine 319, 525-532.

Vogelstein B, Lane D \& Levine AJ (2000) Surfing the p53 network. Nature 408, 307-310.

Voorrips LE, Goldbohm RA, van Poppel G, Sturmans F, Hermus RJ \& van den Brandt PA (2000) Vegetable and fruit consumption and risks of colon and rectal cancer in a prospective cohort study: The Netherlands Cohort Study on Diet and Cancer. American Journal of Epidemiology 152, 1081-1092.

Waddell WR (1998) Stimulation of apoptosis by sulindac and piroxicam. Clinical Science (Colchester) 95, $385-388$.

Waddell WR, Ganser GF, Cerise EJ \& Loughry RW (1989) Sulindac for polyposis of the colon. American Journal of Surgery 157, 175-179.

Wallach D (1997) Apoptosis. Placing death under control. Nature 388, 123, 125-126.

Wasan HS \& Goodlad RA (1996) Fibre-supplemented foods may damage your health. Lancet 348, 319-320.

Wenzel U, Kuntz S, Brendel MD \& Daniel H (2000) Dietary flavone is a potent apoptosis inducer in human colon carcinoma cells. Cancer Research 60, 3823-3831.

Wheeler JM, Bodmer WF \& Mortensen NJ (2000) DNA mismatch repair genes and colorectal cancer. Gut 47, $148-153$.

Winawer SJ (1999) Natural history of colorectal cancer. American Journal of Medicine 106, 3S-6S.

Wright N \& Alison M (1984) Cell proliferation in gastrointestinal carcinogenesis. The Biology of Epithelial Cell Populations, vol. 2, pp. 823-825. Oxford: Clarendon Press.

Wu JT, Archer SY, Hinnebusch B, Meng S \& Hodin RA (2001) Transient vs. prolonged histone hyperacetylation: effects on colon cancer cell growth, differentiation, and apoptosis. American Journal of Physiology, Gastrointestinal and Liver Physiology 280, G482-G490.

Wyllie AH, Bellamy CO, Bubb VJ, Clarke AR, Corbet S, Curtis L, Harrison DJ, Hooper ML, Toft N, Webb S \& Bird CC (1999) Apoptosis and carcinogenesis. British Journal of Cancer 80, Suppl. 1, 34-37.

Wyllie AH, Kerr JF \& Currie AR (1980) Cell death: the significance of apoptosis. International Reviews in Cytology 68, 251-306.

Xu K \& Thornalley PJ (2000) Studies on the mechanism of the inhibition of human leukaemia cell growth by dietary isothiocyanates and their cysteine adducts in vitro. Biochemical Pharmacology 60, 221-231.

Yamamoto M, Tsukamoto T, Sakai H, Shirai N, Ohgaki H, Furihata C, Donehower LA, Yoshida K \& Tatematsu M 
(2000) p53 knockout mice (-/-) are more susceptible than (+/-) or (+/+) mice to N-methyl-N-nitrosourea stomach carcinogenesis. Carcinogenesis 21, 1891-1897.

Yang K, Lamprecht SA, Liu Y, Shinozaki H, Fan K, Leung D, Newmark H, Steele VE, Kelloff GJ \& Lipkin M (2000) Chemoprevention studies of the flavonoids quercetin and rutin in normal and azoxymethane-treated mouse colon. Carcinogenesis 21, 1655-1660.

Yeh WC, Itie A, Elia AJ, Ng M, Shu HB, Wakeham A, Mirtsos C, Suzuki N, Bonnard M, Goeddel DV \& Mak TW (2000) Requirement for Casper (c-FLIP) in regulation of death receptor-induced apoptosis and embryonic development. Immunity 12, 633-642.

Yin XM (2000) Signal transduction mediated by Bid, a pro-death Bcl-2 family protein, connects death receptor and mitochondria apoptosis pathways. Cell Research 10, 161-167.

Yoshida M, Yamamoto M \& Nikaido T (1992) Quercetin arrests human leukemic T-cells in late G1 phase of the cell cycle. Cancer Research 52, 6676-6681.

Yu R, Jiao JJ, Duh JL, Tan TH \& Kong AN (1996) Phenethyl isothiocyanate, a natural chemopreventive agent, activates c-Jun N-terminal kinase 1. Cancer Research 56, 2954-2959.

Yu R, Mandlekar S, Harvey KJ, Ucker DS \& Kong AN (1998) Chemopreventive isothiocyanates induce apoptosis and caspase-3-like protease activity. Cancer Research 58, 402-408.

Yuan J, Shaham S, Ledoux S, Ellis HM \& Horvitz HR (1993) The C. elegans cell death gene ced-3 encodes a protein similar to mammalian interleukin-1 beta-converting enzyme. Cell 75, 641-652.

Zhang H, Richards B, Wilson T, Lloyd M, Cranston A, Thorburn A, Fishel R \& Meuth M (1999) Apoptosis induced by overexpression of hMSH2 or hMLH1. Cancer Research 59, 3021-3027.

Zsolnai T (1971) Antimicrobial effects of thiocyanates, isothiocyanates and potential isothiocyanate forming substances. Arzneimittelforschung 21, 121-127. 